Hastewell Linley John (Orcid ID: 0000-0003-1600-1369)

Schaefer Martin (Orcid ID: 0000-0003-4905-1354)

\title{
Quantification of contemporary storm-induced boulder transport on an intertidal shore platform using Radio Frequency Identification (RFID) technology.
}

Dr. Linley Hastewell*, University of Portsmouth, School of the Environment, Geography \& Geosciences, Buckingham Building, Lion Terrace, Portsmouth, PO1 3HE. Corresponding author (linley.hastewell@port.ac.uk).

Dr. Robert Inkpen, University of Portsmouth, School of the Environment, Geography

\& Geosciences, Buckingham Building, Lion Terrace, Portsmouth, PO1 3HE.

Dr. Malcolm Bray, University of Portsmouth, School of the Environment, Geography \& Geosciences, Buckingham Building, Lion Terrace, Portsmouth, PO1 3HE.

Martin Schaefer, University of Portsmouth, School of the Environment, Geography \& Geosciences, Buckingham Building, Lion Terrace, Portsmouth, PO1 3HE.

Running Head: Quantification of contemporary storm-induced boulder transport

This article has been accepted for publication and undergone full peer review but has not been through the copyediting, typesetting, pagination and proofreading process which may lead to differences between this version and the Version of Record. Please cite this article as doi: $10.1002 /$ esp.4834 


\section{ABSTRACT}

Extreme storm events are known to produce, entrain, transport and deposit sizable boulders along rocky coastlines. However, the extent to which these processes occur under moderate, fetch-limited wave conditions is seldom considered. In this study we quantify boulder transport at a relatively sheltered location subjected to high frequency, low magnitude storm activity. This was achieved by deploying Radio Frequency Identification (RFID) tags within 104 intertidal limestone boulders ranging in size from fine to very coarse (intermediate axis: $0.27-2.85 \mathrm{~m}$ ). The study was conducted over three years (July 2015 - July 2018) and encompassed numerous storm events. Tagged boulders were relocated during 17 field surveys and their positions recorded using Differential Global Positioning Navigation Satellite System (DGNSS).

On completion, we identified boulder displacement in $69 \%$ of the tagged array. The accrued boulder transport distance amounted to $233.0 \mathrm{~m}$ from 195 incidents of displacement including the movement of a boulder weighing an estimated 11.9 tonnes. Transport was not confined to autumn and winter storms alone as displacement was also recorded during summer months (April - September) despite the seasonally reduced wave magnitude.

Boulder production by wave quarrying was documented in three tagged clasts confirming observations that the shore platform is actively eroding. Incidents of overturning during transport were also recorded including multiple overturning of clasts weighing up to 5 tonnes. We further identify a statistically significant difference (maximum $p$-value: $\leq 0.03$ ) between the transport distances attributed to constrained 
and unconstrained boulders suggesting the pre-transport morphological setting exerts considerable control over boulder transport potential.

The findings establish low to moderate storm waves as a key component in the evolution of the study site. More broadly, we claim that high frequency, low magnitude storms regularly modify these overlooked rocky coastal locations suggesting the hydrodynamic capability at such sites may have been previously underestimated.

Keywords: boulder transport, storm response, RFID tagging, storm events, rocky coasts

\section{INTRODUCTION}

Rocky coasts are susceptible to geomorphological change by a range of erosive agents. This is manifest most profoundly by the presence of large coastal boulder deposits which are frequently found on exposed intertidal shore platforms and supratidal cliff-tops (Stephenson and Naylor, 2011; Etienne and Paris, 2010; Hall et al., 2006; Cox et al., 2018, Biolchi et al., 2019). The emplacement of such deposits act as signatures of past extreme wave events (Mastronuzzi and Sansò, 2000; Williams and Hall, 2004; Scheffers et al., 2009; Barbano et al., 2010; Goto et al., 2010a; Paris et al., 2011; Shah-hosseini et al., 2011; Lau et al., 2016) and reflect the magnitude of the wave activity that initiated boulder production, transport and deposition (Nott, 2003;

Goto et al., 2009; Nandasena et al., 2011; Nandasena and Tanaka, 2013a; RoigMunar et al., 2019). Consequently these boulders have been used as proxies for extreme storm events including typhoon/hurricane/cyclone generated storms (Scheffers and Scheffers, 2006; Fichaut and Suanez, 2011; Cox et al., 2012; Terry et al., 2016; Kennedy et al., 2017; Cox et al., 2018; Terry and Lau, 2018), and/or tsunami 
(Scicchitano et al., 2007; Maouche et al., 2009; Etienne et al., 2011; Engel and May, 2012; Mottershead et al., 2014).

Contemporary storm events have also been reported as capable of producing, entraining and transporting intertidal and supratidal clasts (Goto et al., 2011; Naylor et al., 2016; Autret et al., 2018; Biolchi et al., 2019a; Biolchi et al., 2019b). However, previous studies commonly address boulder displacement at exposed sites which are subjected to high magnitude, low frequency storm events (Goto et al., 2009; Hansom and Hall, 2009; Etienne and Paris, 2010; Autret et al., 2016). Coastal sites subjected to low and moderate wave climates have been widely overlooked (Dasgupta 2010) despite the presence of boulder assemblages indicative of storm wave deposition. Furthermore, a lack of emperical, field data on the extent to which intertidal boulders respond to contemporary low magnitude, high frequency storm events remains unexplored and unknown (Paris et al., 2011).

This sediment tracing study aims to broaden our current understanding of boulder transport processes by quantifying boulder transport at two separate sites, (Bembridge Ledge and Black Rock) on the relatively sheltered east coast of the Isle of Wight (U.K.). The location has a limited fetch and low to moderate wave regime (Hastewell et al., 2019a). Boulder displacement has been monitored over a three year period using 104 intertidal limestone boulders, each embedded with a Radio Frequency Identification (RFID) tag. The tagged boulders were periodically relocated during field surveys and their positions recorded using Differential Global Positioning Navigation Satellite System (DGNSS).

In the course of fulfilling the study aim we further develop previous work by Naylor and Stephenson (2010); Stephenson and Naylor, (2011); Naylor et al, (2016) in identifying 
the key mechanisms that facilitate boulder production, the removal of blocks from the shore platform bedrock and highlight the significance of platform morphology on boulder transport capability.

Inshore and nearshore wave data and tidal parameters were recorded throughout the study at two wave monitoring stations approximately $5 \mathrm{~km}$ from the study sites. The data provides insight to the hydrodynamic conditions that we infer initiated episodes of boulder displacement.

The transport of intertidal boulders presented herein provides a greater understanding of the responsiveness of rocky coasts to contemporary, high frequency, low magnitude storm events and the underlying processes and mechanisms that influence boulder production, transport and deposition within the intertidal zone. The findings will be of increased significance given the changing climate is predicted to invoke an increase in storm frequency and intensity (Leckebusch et al., 2006; Beniston et al., 2007) which is expected to alter future wave climates, tidal regimes and sediment transport patterns and potentially increase rates of erosion at rocky coasts (Trenhaile, 2016).

\section{SITE LOCATION}

Bembridge is located on the east coast of the Isle of Wight, southern England and comprises a $4 \mathrm{~km}$ shoreline fronted by a wide shore platfrom, Figure 1 . The study site is comprised of near-horizontal beds of late Eocene Bembridge Limestone interspersed with less resistant Bembridge Marls (Armenteros and Daley, 1998; Insole

et al., 1998). The limestone beds form extensive intertidal shore platforms characteristic of type-B shore platforms, being near/sub-horizontal with an abrupt seaward terminus (Trenhaile, 1987; Sunamura, 1992). 
The tidal regime is classified as meso-tidal with a neap and spring tidal range of $1.8 \mathrm{~m}$ and $3.7 \mathrm{~m}$ respectively. Bembridge has a limited fetch ranging from $140 \mathrm{~km}$ to the south and $185 \mathrm{~km}$ to the east (Hastewell et al., 2019a). Its location on the east coast of the Isle of Wight provides shelter from Atlantic swell waves and the prevailing southwesterly wind direction.

Two survey sites were selected, each covering approximately $0.1 \mathrm{~km}^{2}$, Bembridge Ledge and Black Rock, herein referred to as BL and BR respectively. Site selection was based on accessible intertidal boulders that were known to be mobile under low to moderate wave conditions. This was evident from the presence of sedimentary signatures and assemblages, including the deposition of individual clasts and a boulder berm, which are indicative of storm-induced transport (Figures 2 and 3). Furthermore, surface striations and abrasion trails located on the platform suggest frequent block displacement (Hall et al., 2008; Cullen and Bourke, 2018). By using two sites with differing coastal aspects it was possible to study the effects of coastal orientation and storm exposure on boulder displacement. Furthermore, unlike many previously studied boulder transport sites Bembridge has not been subjected to any recent paleotsunamigenic impacts (Long, 2017). The lack of a competing mechanism allows us to ascribe boulder transport and the formation of associated geomorphic features to storm-driven activity alone.

\section{Bembridge Ledge (BL)}

$\mathrm{BL}$ is comprised of a tiered intertidal, easterly oriented, shore platform, the lowest of which extends $500 \mathrm{~m}$ at its widest point. Collectively, the platforms are similar in form to those depicted and described by Hills (1972, p.87) as a "terraced platform with several low terraces." The landward platform edge ranges in height from $0.2-1.0 \mathrm{~m}$ 
and is densely jointed with discontinuities orientated predominantly to the north and east, towards incoming wave energy. This lithological characteristic promotes block removal at the platform edge which provides source material for transport to occur, Figure 2a.

Boulders are transported landward across the near-horizontal $\left(0^{\circ}\right.$ to $\left.+1^{\circ}\right)$ wave scoured platform which varies in width from $5 \mathrm{~m}$ to $55 \mathrm{~m}$. Boulders are found most frequently as solitary clasts on the upper platform surface or emplaced and occasionally buried within the mixed sand and gravel beach that fronts a low cliff formed in a Quaternary raised beach deposit (Insole et al., 1998). The beach dissipates wave energy, reducing transport capacity resulting in boulder deposition (Buscombe and Masselink, 2006; Almeida et al., 2015), Figure 2b.

Platform topography is generally smooth, with the exception of the occasional raised scarp, ranging from $0.1 \mathrm{~m}$ and $0.5 \mathrm{~m}$ in height. Additionally, a series of shallow intertidal pools cover an area of the platform $\left(0.007 \mathrm{~km}^{2}\right)$. The pools are encircled by raised rims, approximately $0.10 \mathrm{~m}$ in height. Isolated boulders are located within the pools which impede further transport, Figure 2c, (Hastewell et al., 2019b).

\section{Black Rock (BR)}

The southerly oriented, limestone unit that forms the seaward shore platform is of greater bed thickness with fewer geological discontinuities when compared with BL and hence it produces boulders of greater size, generally ranging from medium (intermediate axis $0.5 \mathrm{~m}$ to $1.0 \mathrm{~m}$ ) to very coarse (intermediate axis $2.0 \mathrm{~m}$ to $4.1 \mathrm{~m}$ ), after Blair and McPherson (1999). 
The seaward platform edge is between $1.0-1.5 \mathrm{~m}$ in height and is defined as horizontal $\left(0^{\circ}\right)$ to sub-horizontal in places with a slight landward dip $\left(-1^{\circ}\right)$. The wave scoured platform is devoid of structural impediments which facilitates transport across the platform surface (Pérez-Alberti and Trenhaile, 2015). Generally, only the largest boulders are located on the exposed platform surface as wave energies are sufficient to facilitate the removal of small and medium sized clasts. Where boulders are present they are found as solitary clasts located between the platform edge and a boulder beach that extends in to a boulder berm which lies between $5 \mathrm{~m}$ and $25 \mathrm{~m}$ from the platform edge, Figure 3a.

The boulder beach and berm hinder landward transport by trapping and accumulating displaced clasts. Both features are interpreted as distinctive sedimentary signatures of boulder transport and deposition. The seaward margin of the boulder beach and berm is characterised by imbricate, stacked clasts indicative of storm deposition (Nott, 2003; Switzer and Burston, 2010), Figure 3b. The boulder beach covers an area of approximately $0.002 \mathrm{~km}^{2}$ and is comprised of fine to coarse clasts. The berm consists of fine to very coarse clasts and extends $0.8 \mathrm{~km}$ from west to east, parallel with the platform edge. Berm width varies from $5 \mathrm{~m}$ to $20 \mathrm{~m}$.

To the rear of the berm lies a tidal lagoon with scattered cobbles on its bed. Platform topography then rises to the edge of a second, more landward horizontal $\left(0^{\circ}\right)$ intertidal rocky outcrop (upper platform) from which small boulders are detached, transported and deposited sporadically on the upper platform, Figure 3c. 


\section{METHODS}

We employed RFID tagging technology to monitor and quantify the displacement of an array of tagged boulders. This was achieved by recording the coordinates of each tagged boulder at the time of tag deployment. Subsequent field surveys were undertaken to relocate the clasts and rerecord their coordinate locations thus providing a spatial and temporal framework within which to quantify clast displacement. However, as with all sediment tracing studies prior to tag deployment it is necessary to ensure the tagged material accurately reflects the physical properties (e.g. size and shape) of the indigenous sediments (Lee et al., 2000; Sear et al., 2000).

\section{Boulder selection}

\section{Size}

Size homogeneity between indigenous and tagged boulders was achieved by conducting an assessment of the boulder populations prior to tag deployment. This data was used to inform tagged boulder selection. Measurements of the long $(L)$, intermediate $(I$ and short $(S)$ axial dimensions of 100 randomly selected boulders at each site allowed for the classification of boulders by size, adopting the nomenclature of Blair and McPherson (1999). A comparison between the percentage frequency of the assigned size classifications between the indigenous and tagged boulders demonstrates that a representative sample has been achieved in terms of size, Figure 4

\section{Shape}

Axial dimensions of indigenous and tagged boulders were used to determine clast shape based on Zingg (1935). Figures $5 \mathrm{a}$ and $5 \mathrm{~b}$ identify the majority of boulders at both sites as disk-shaped (BL: tagged: $65 \%$ / indigenous: $66 \%$ and BR: tagged: $46 \%$ 
/ indigenous: $49 \%$ ). The greater number of disk-shaped clasts at $\mathrm{BL}$, and the limited variability in shape is attributed to the relative consistency in the short axis of the $B L$ clasts (mean c-axis: $0.27 \mathrm{~m}$ ) which corresponds with the mean thickness of the boulder producing limestone unit exposed at the platform edge (approximately $0.25 \mathrm{~m}$ ). This supports boulder provenance and suggests clast size is litho-structurally controlled (Stephenson and Naylor, 2011; Salzmann and Green, 2012).

On the basis of our preliminary assessment we assert that the physical properties (size and shape) of the tagged boulders are comparable with the indigenous boulder population.

\section{Morphological setting}

The position of a boulder prior to displacement is reported to be a key component in controlling its transport potential (Naylor et al., 2016; Zainali and Weiss 2015; Nott, 2003; Spiske and Bahlburg, 2011; Nandasena et al., 2011; Switzer and Burston, 2010). Therefore, tagged boulders were selected to reflect a range of different morphological settings (MS), as defined in Hastewell et al, (2019a) to establish its significance on transport distance. Figure 6 provides examples for each MS from Bembridge Ledge.

Each morphological setting is defined by the potential for a boulder to be displaced. These boulders are referred to as being either constrained or unconstrained (Trenhaile 2016). Of the four MS's, three are designated as constrained (MS1, MS2 and MS3) meaning boulder transport is impeded by a range of geomorphic and/or topographic landform features such as the gravel beach, boulder beach/berm and/or imbricate boulders. Unconstrained clasts are represented in MS4; these clasts are unimpeded in their ability to be displaced. It was hypothesised that unconstrained boulders (MS4) 
would be mobilised more frequently and over greater distance when compared with constrained clasts represented in other MS's.

Of the 50 tagged boulders within the $B L$ study area; $60 \%$ were located on the platform and gravel beach, the remaining $40 \%$ were positioned on the seaward side of the platform edge. At BR, $74 \%$ of the tagged boulders were located on the seaward platform, the remaining $26 \%$ on the upper platform. There were no tagged boulders located seaward of the platform terminus at BR as the low water (LW) level would restrict access to spring tides only.

\section{RFID}

RFID technology has been used previously in littoral studies as a means of monitoring the incremental displacements of a range of sediment sizes. Previous studies have concentrated on mixed sediments including gravel, cobbles and small boulders (Allan et al., 2006; Nichols, 2004; Dickson et al., 2011; Miller et al., 2011; Brayne, 2015; Casamayor et al., 2015; Dolphin et al., 2016; Han et al., 2017) as opposed to focusing purely on boulder-sized clasts. As such, this research forms the first long-term, monitoring study to quantify intertidal boulder transport using RFID tagging.

RFID technology was favoured over alternative methods of boulder tracing such as marine paint (Stephenson and Naylor, 2011; Naylor et al., 2016) as the sensitive environmental designations at the Bembridge sites required a discrete and unobtrusive means of clast identification. Furthermore, unlike painted clasts RFID technology enables the detection of buried material which results in improved rates of tag recovery (Bray et al., 1996). 
RFID equipment consists of a transponder, referred to as a tag, an antenna, powered by the backpack reader and a handheld user interface (PDA), Figure 7 . With no internal power source, the RFID tag is small enough to be embedded within a boulder (deployed tag size $32 \times 4 \mathrm{~mm}$ ). Each tag has a pre-programmed 16-digit reference number that enables the unequivocal identification of tagged material in the field.

Tagged boulders were (re)located using the antenna. When in range, the tag transmits its unique reference number which is displayed on the handheld interface enabling the identification of the embedded tag and associated boulder.

\section{RFID tagging protocol}

The application of RFID technology to monitor boulder transport is comprehensively described in Hastewell et al, (2019a) and is briefly summarised below. RFID tags were securely embedded within selected boulders using a waterproof sealant and marine epoxy resin; referred to as the tag insertion point (TIP). The TIP was used as a fixed point from which the boulder coordinates were recorded during tagged boulder relocation surveys. Coordinate data was recorded using a Topcon Hiper V in real-time kinematic (RTK) mode (referred to as the DGNSS) which provided a relative horizontal accuracy of $5 \mathrm{~mm},+/-0.5 \mathrm{ppm}$ (Topcon, 2018). An additional hole was drilled above the TIP to indicate the upward orientation of the boulder at the time of deployment, referred to as the orientation hole. This was used as an indicator of the transport mode; any relocated boulder found with the orientation hole below the tag was identified as being overturned during transport. 


\section{Boulder transport}

The boulder transport data is based on findings from a three year study (July 2015 July 2018). Transport pathways were quantified using RFID tags embedded in 104 intertidal limestone boulders; 50 at Bembridge Ledge and 54 at Black Rock. The tagged boulders were relocated during low water using the RFID detection equipment; 17 relocation surveys were conducted ( 8 at BL and 9 at BR), Table I.

\section{Insert Table I.}

Once relocated, the boulder coordinates were rerecorded using the DGNSS. The data was stored with the unique tag ID code for processing. By conducting repeat surveys, a series of coordinate points $(x, y, z)$ for each tagged boulder was generated. The coordinate data was processed in ArcGIS (vers. 10.5) using a Python script which calculated the distance and azimuth between successive points providing a spatial and temporal frame within which individual boulder transport pathways could be determined and accurately quantified. The Python script is included in the supplementary material.

Geomorphological surveys were conducted concurrently during relocation surveys. General site observations including evidence of block detachment and transport were recorded using a digital camera. This empirical data complimented the quantitative transport data allowing us to theorise mechanisms of boulder production and transport.

A threshold value was established to differentiate entrainment from transport. This was based on the combined errors associated with the relative accuracy of the DGNSS, the setup of the base station and the RMSE of resurveying the TIP. Based on the cumulative values we conservatively set the horizontal and vertical error at $0.1 \mathrm{~m}$. 
Therefore, the entrainment/transport threshold value was set at $0.1 \mathrm{~m}$. Transport values calculated via the Python script exceeding $0.1 \mathrm{~m}$ were defined as transported; values below $0.1 \mathrm{~m}$ were classified as static and/or entrained only. Subsequently, those values $<0.1 \mathrm{~m}$ were not incorporated into any transport distance values. Additional detail on the entrainment/transport threshold is addressed in Hastewell et al. (2019a).

\section{Wave climate and tidal regime}

Wave induced erosion is considered significant in modulating geomorphic change on rocky coasts (Trenhaile, 1987; Ogawa et al., 2011). Therefore, an understanding of the wave conditions relative to periods of mobility is necessary to better understand wave transport processes. Wave and tidal data was obtained from two wavemonitoring stations managed by the Channel Coast Observatory (CCO). A WaveRider REX system located on Sandown Pier approximately $6 \mathrm{~km}$ southwest of the study site provided inshore wave conditions including wave period (seconds), significant wave height in metres $\left(H_{s}\right)$ and maximum wave height $\left(H_{\max }\right)$. Tidal levels were also recorded. In addition, a WaveRider buoy located $5 \mathrm{~km}$ to the southwest of the study site, $1.2 \mathrm{~km}$ from the coast in a water depth of approximately $8.0 \mathrm{~m}(\mathrm{OD})$ provided data on the nearshore wave direction, wave period, $\mathrm{H}_{\mathrm{s}}$ and $\mathrm{H}_{\max }$ values (Figure $1 \mathrm{~b}$ ). Wave data was recorded every 30 minutes, tidal every 10 minutes.

To define storm activity we apply the CCO storm threshold value of $1.6 \mathrm{~m}$ for the Sandown Pier monitoring station. This figure is based on extreme value analysis of wave data which identifies the 0.25 year return period for significant wave height $\left(H_{s}\right)$, i.e. the wave value exceeded on average four times per year (CCO 2018). When 
referring to the nearshore wave buoy we adopt the storm threshold of $2.5 \mathrm{~m}$ (CCO 2015).

Wave data from the inshore pier monitoring station was used to infer the storm conditions that occured at Bembridge, thus providing estimates of the wave conditions that facilitated block detachment and displacement. Field observations indicated that the inshore wave data better reflected the wave conditions encountered at the study site therefore it was favoured over the nearshore alternative. Furthermore, Héquette and Cartier (2016) recommend the use of wave parameters recorded closer to shore opposed to data derived offshore as a greater degree of interaction with seafloor bathymetry alters wave characteristics.

\section{RESULTS}

\section{RFID recovery rates}

On completion of the three year study a mean RFID tag recovery rate of $92 \%$ was achieved ( $88 \%$ at $\mathrm{BL}$ and $96 \%$ at $\mathrm{BR})$. The high rate of recovery is unprecedented in previously reported littoral tracer studies over similar timescales (Chapuis et al., 2014; Hastewell et al., 2019a). Tag recovery rates at BL were affected by burial of tagged boulders within the beach matrix following the seasonal accretion of sands and gravel. Unfavourable tidal and wave conditions during three BR surveys prevented safe access to a number of boulders located near the LW mark which affected the relocation of some tagged clasts.

\section{Boulder production}

Findings from geomorphological surveys undertaken at both sites provided a basis upon which we propose the mechanisms by which boulder production occurred. At BL 
block removal is controlled by the litho-structural characteristics of the shore platform bedrock. The heavily jointed and clearly defined bedding is exploited by breaking waves promoting detachment by wave quarrying of fracture-bound angular blocks (Naylor and Stephenson, 2010). Quarrying occurs where the ingress of water from breaking waves penetrates into the joints and bedding planes that separate individual blocks. Air pressure within the joints and planes increases leading to crack propagation that eventually liberates the block from its adjacent neighbours (Stephenson and Kirk, 2000; Trenhaile and Kanyaya, 2007, Trenhaile, 2019), Figure 8 , inset a. Boulder production is also initiated by undermining, whereby a consolidated limestone unit lies above a thin bed of clay-rich marl. The preferential erosion of the subjacent marl layer creates an overhang. As the overhang increases, the overlaying blocks fracture along existing discontinuities (Switzer and Burston, 2010; Herterich et al., 2018), Figure 8, inset b. Liberated blocks are deposited immediately seaward of the platform edge where repeated block detachment generates an accumulation of boulders which act as source material for landward transport, Figure 8.

At BR the lithology of the unit facilitates a mode of detachment that is dominated by undermining around the mean low water mark. Abrasive material (gravels and cobbles) mobilised by wave-driven currents have created a notch within the limestone unit beneath the shore platform edge (Trenhaile, 2015). Gravity loading of the overburden eventually overcomes material rock strength causing tension cracks resulting in block failure and detachment (Kogure et al., 2006), Figure 9, inset a. As with $\mathrm{BL}$, the detached material accumulates at the front of the platform producing a debris apron which allows for individual boulders to be elevated on to the platform surface, Figure 9. 


\section{Boulder transport}

The relocated tagged boulder coordinate data was utilised to quantify clast displacement. This was achieved by processing the coordinate data in ArcGIS (vers. 10.5) via a Python script. The geospatial data output provided values for the distance and direction of transport between previously recorded coordinate points. The data identified the individual boulder transport distance (IBTD) for each tagged clast between surveys. Tables II and III present data for each mobile tagged boulder and include characteristics such as the axial dimensions, morphological setting (MS) and mass, amongst others. Python outputs for distance $(\mathrm{m})$ and direction $\left({ }^{\circ}\right)$ of displacement for individual transport events are also reported relative to the specific survey periods, as dated. Incidents of overturning are highlighted by the shaded cells. Transport events resulting in boulder transfer between MS's are identified in bold and italicised text along with the associated transport distance and direction that was recorded. Those boulders identified by the MS prefix/suffix nomenclature e.g. MS4/3 were originally located in MS4 then subsequently transferred to MS3. Immobile boulder details are not included in these tables.

Additional site specific transport data for $\mathrm{BL}$ and $\mathrm{BR}$, and inshore wave conditions relative to each survey period are available in the supplementary material.

The mass of displaced boulders at $\mathrm{BL}$ ranged from $0.1 \mathrm{t}$ to $1.3 \mathrm{t}$. At $\mathrm{BR}$, mobile boulder mass ranged from $0.1 \mathrm{t}$ to $11.9 \mathrm{t}$. At both sites the a-axis orientation of tagged boulders was generally aligned perpendicular to the direction of transport (Nott, 2003), Figures $10(\mathrm{BL})$ and $11(\mathrm{BR})$. Transport occurred relative to the prevailing wave direction from within the south-eastern quadrant. The easterly aspect of BL affords a greater level of 
shelter from the dominant south-south-westerly (SSW) wind and southerly wave approach when compared with BR.

\section{Morphological classification}

Each boulder was classified within a specific MS in accordance with the categories identified in Figure 6. This enabled each transport event to be assigned to a specific MS. The collated data is presented in Table IV.

IBTD values for mobile clasts were plotted relative to the MS within which transport occurred, Figures $12 \mathrm{a}$ and $12 \mathrm{~b}$. Each incremental transport event $\geq 0.1 \mathrm{~m}$ is represented by the respective symbol identified in the legend. Enlarged symbols indicate an incident of overturning. Boulders identified by the MS prefix/suffix nomenclature e.g. MS4/3 were originally located in MS4 (unconstrained) then subsequently transferred to MS3 (constrained). The figures demonstrate graphically the apparent significance of the morphological setting (constrained versus unconstrained) on the recorded boulder tranport values.

\section{Wave climate and tidal regime}

Analysis of the CCO wave data over the study period identified maximum inshore $\mathrm{H}_{\mathrm{s}}$ and $H_{\max }$ values of $2.3 \mathrm{~m}$ and $3.3 \mathrm{~m}$ respectively $(\mathrm{CCO}, 2018)$. Inshore $\mathrm{H}_{\mathrm{s}}$ exceeded the CCO storm threshold of $1.6 \mathrm{~m}$ on 42 occasions representing $0.07 \%$ of the total number of recorded $\mathrm{H}_{\mathrm{s}}$ wave values $(n=63741) ; \mathrm{H}_{\max }$ values exceeded the threshold 817 times representing $1.28 \%$ of the total number of recorded wave values ( $n=$ 63741). Inshore wave heights $\left(H_{s}\right.$ and $\left.H_{\max }\right)$ recorded during the study period are presented relative to the tagged boulder relocation surveys and the CCO storm threshold, Figure 13. Inshore directional wave data is not available. 
Data from the nearshore wave buoy identified that $H_{s}$ values exceeded the storm threshold of $2.5 \mathrm{~m}$ on 85 occasions representing $0.16 \%$ of the total number of recorded $H_{s}$ wave values $(n=51695)$. $H_{\max }$ waves exceeded the threshold 1022 times representing $1.97 \%$ of the total number of recorded wave values $(n=50743) . \mathrm{H}_{\mathrm{s}}$ and $\mathrm{H}_{\max }$ wave heights exceeding the $2.5 \mathrm{~m}$ threshold are presented in Figures $14 \mathrm{a}$ and 14b. The data identifies storm wave activity and intensity as dominant from a SSE direction, mean wave orientation was $164^{\circ},+/-30^{\circ}$. This aligns with the southerly aspect of the shore platfrom at BR but would strike BL at an oblique angle. Notably, a smaller proportion of the $\mathrm{H}_{\max }$ waves originate from an ESE direction, which could directly impact BL.

\section{DISCUSSION}

\section{Boulder production}

The deployment of RFID tagged boulders aided the identification of boulder production. Incidents of detachment amongst the tagged boulder array were recorded on three occasions at BL; detachment was not directly observed at BR. We propose the increased occurrence of block removal by quarrying at BL was associated with the denser structural jointing and reduced bed thickness of the limestone units when compared with BR. This draws comparison with Kennedy, (2010), Naylor and Stephenson, (2010), Naylor et al, (2016) and Buchanan et al, (2020) who suggest boulder production is influenced by site-specific litho-structural controls.

We present an example of boulder production by quarrying at BL (tag ID: 1148), Figure 15. The pre-transport tagged boulder was integrated as part of the shore platform edge prior to detachment, as recorded on 25 July 2015. The dotted line represents the welldefined joints that enable water ingress from breaking waves, Figure 15a. During a 
relocation survey on 3 February 2016 the tagged block had become detached from the bedrock strata. The remnants of block removal are illustrated by a socket which clearly displays differing colouration from the surrounding bedrock unit indicating recent exhumation, Figure 15b. The same quarrying signature was observed by Hall et al. (2008) on the coast of Shetland (Scotland) and by Knight and Burningham (2011) on the northwest coast of Ireland. The detached boulder was relocated $15.0 \mathrm{~m}$ from the socket having been overturned during transport as indicated by the downward position of the orientation hole. The boulders landward trajectory was impeded by a raised scarp $(0.2 \mathrm{~m})$ suggesting local morphological features exert influence on boulder transport, Figure $15 \mathrm{c}$ and $15 \mathrm{~d}$.

Whilst quantifying volumetric meso-erosion at the platform edge was not in the scope of this study recorded block removal signifies erosion readily occurs at the platform terminus. Given the protective role of shore platforms in dissipating wave energy (Stephenson and Kirk, 2000) any erosion to the platform presents the increased prospect of denudation at the cliff/platform interface. This is of significance when considering the susceptibility to erosive forces of the weakly consolidated raised beach deposit at BL. Such active erosion presents societal implications with regards to loss of natural capital and risk associated with damage to businesses, housing and the associated infrastructure, Figures $15 \mathrm{~d}$.

\section{Boulder transport}

Despite the moderate storm wave climate compared with previous boulder transport study sites (Hall et al., 2008; Goto et al., 2009; Knight and Burningham, 2011; Cox et al., 2012; Autret et al., 2016; Naylor et al., 2016) our data demonstrates that extreme storm conditions are not necessary to mobilise boulder-sized clasts. 
The total distance of boulder transport measured over the three year study amounted to $233.0 \mathrm{~m}, 66 \%(152.8 \mathrm{~m})$ occurring at $\mathrm{BL}$ and $34 \%(80.2 \mathrm{~m})$ at $\mathrm{BR}$. This resulted from 195 individual transport events each $\geq 0.1 \mathrm{~m}, 57 \%(n=112)$ occurred at $\mathrm{BL}, 43 \%$ ( $n=83)$ at BR. Of the 104 boulders in the array, $69 \%(n=72)$ were mobile at least once over distances ranging from $0.1 \mathrm{~m}$ to $21.5 \mathrm{~m}$ with a greater number of mobile clasts at BL: $39 / 50$ (78\%) than BR: 33/54 (61\%). Of the 72 displaced boulders, $11 \%$ were mobilised on five or more separate occasions. Transported boulders were represented in each of the boulder size categories (Blair and McPherson, 1999) including a very coarse clast (estimated mass: $11.9 \mathrm{t}$ - tag ID: 1188) that was transported twice accumulating an IBTD of $3.6 \mathrm{~m}$. Furthermore, the study total for transport distance at BL was $90 \%$ higher than at BR. We attribute this, in part, to lithostructural differences in the boulder producing bedrock units at the sites (Cruslock et al., 2010; Stephenson and Naylor, 2011; Naylor and Stephenson, 2010). The more densely jointed bedrock at BL produces a greater number of smaller, mobile clasts compared to BR (BL: mean tagged boulder mass $=0.5 \mathrm{t} / \max .1 .3 \mathrm{t}$ and BR: mean $=$ $1.1 \mathrm{t} / \max .11 .9 \mathrm{t})$.

By comparison, Naylor et al. (2016) conducted a 4-day boulder transport study documenting the displacement of 46 painted clasts (coarse cobbles to medium boulders) during an extra-tropical cyclonic storm in 2008. Recorded transport distances were generally higher than those reported herein with a number of clasts being displaced over several tens of metres; maximum net transport distance of a single boulder, $91.2 \mathrm{~m}$. However, wave conditions were reportedly greater $\left(\mathrm{H}_{\max }\right.$ of $5.96 \mathrm{~m}$ ) and boulder mass was generally lower, (ranging from $0.014 \mathrm{t}-0.73 \mathrm{t}$ ) than the Bembridge tagged clasts. 
Seasonality of boulder displacement was evident with increased transport occurring between September and February, corresponding with greater wave magnitudes associated with autumn and winter storm events. However, the longevity of the study demonstrated that transport also occurred during periods of perceived quiescence, e.g. spring and summer months (April - September). The transport data identified boulder displacement occurred even under low energy wave conditions when the inshore $\mathrm{H}_{\mathrm{s}}$ failed to breach the CCO storm threshold of $1.6 \mathrm{~m}$. At BL between 1 April and 23 September 2016, 11 transport events occurred amounting to displacement of $5.5 \mathrm{~m}, 4 \%$ of the BL study total of $152.8 \mathrm{~m}$, (mean transported boulder mass, $0.5 \mathrm{t}$ ). At BR between 31 May and 1 September 2016 transport of $1.3 \mathrm{~m}, 2 \%$ of the BR study total of $80.2 \mathrm{~m}$ was recorded from four transport events, (mean transported boulder mass, $0.4 \mathrm{t})$. The maximum recorded inshore wave height $\left(\mathrm{H}_{\mathrm{s}}\right)$ during these periods was $1.5 \mathrm{~m}$ and $1.0 \mathrm{~m}$ respectively.

The output from the Python script detailed transport distance $(\mathrm{m})$ and the direction of displacement between points $\left(^{\circ}\right)$. This provided insight to the boulder transport pathways and clast deposition. Notably, the dominant direction of transport at BL occurred between $270^{\circ}$ and $0^{\circ}$, at BR this occurred in a northerly direction, between $315^{\circ}$ and $45^{\circ}$. Transport at both sites appears to be closely aligned with the prevailing southerly wave approach. The directional transport data was applied to the shoreline orientation at each site to establish the onshore/offshore sediment flux. The general orientation of the platform edge at BL runs from north to south, thus transport orientated between $0^{\circ}$ and $180^{\circ}$ was regarded as transported offshore. Transport between $180^{\circ}$ and $360^{\circ}$ was deemed to be transported onshore. The data identified $80 \%(123.0 \mathrm{~m})$ of the $152.8 \mathrm{~m}$ study total at BL was transported onshore, the remaining $20 \%(29.8 \mathrm{~m})$ offshore, Figure 16a. Conversely, the platform edge at BR is orientated 
east to west. Therefore, transport orientated between $90^{\circ}$ and $270^{\circ}$ was considered offshore transport, instances orientated between $270^{\circ}$ and $90^{\circ}$ were classed as onshore transport. Of the $80.2 \mathrm{~m}$ study total, $81 \%(64.9 \mathrm{~m})$ was orientated onshore, $19 \%(15.3 \mathrm{~m})$ offshore, Figure 16b.

At both sites the majority ( $80 \%)$ of boulder transport resulted in onshore deposition as dictated by the dominant storm wave approach at, and across the shore platform surface. The higher percentage values for onshore transport suggest both sites are depositional with regard to boulder-sized sediments. This may be beneficial with continued clast deposition reducing wave attenuation across the shore platform minimising the wave energy delivered to the cliff/platform interface (Trenhaile, 2016). The orientation of the platform edge at $\mathrm{BL}$ relative to the prevailing wave activity produces more cross-shore boulder transport than at BR. Furthermore, the offshore transport at both sites indicates that wave backwash is capable of mobilising bouldersized clasts (Knight et al., 2009; Knight and Burningham, 2011).

Boulder deposition by storm waves was apparent from the recorded a-axis orientation of each tagged boulder. The a-axis is reported to be aligned parallel to the shore platform and/or perpendicular to the direction of storm wave approach (Nott, 2003; Salzmann and Green, 2012). At BL, 74\% of a-axis orientations were aligned between $315^{\circ}$ and $45^{\circ}$. At BR, $70 \%$ were aligned between $45^{\circ}$ and $135^{\circ}$. Figures 10 (BL) and 11 (BR) highlight the general trend of tagged boulder alignment parallel with the shore platform edge, indicative of transport under storm wave conditions. McKenna (2005) suggests, not only is a-axis orientation a reflection of storm wave approach but also the lack of an orientational trend may result from boulder collision. The field evidence and presence of widely scattered individual clasts on the platforms suggests boulder- 
boulder interactions are likely to be infrequent and do not significantly impact on boulder transport potential.

Although the field data affirms that low to moderate storm waves facilitate boulder transport the complexity of the mechanisms and processes that enable such transport require further investigation. Previous research has indicated a range of parameters exert influence on boulder displacement including geological discontinuities (Naylor and Stephenson, 2011; McKenna et al., 2011), boulder mass (Goto et al, 2011), shape (Imamura et al., 2008), pre-transport setting (Nandasena et al., 2011; Nott, 2003), surface roughness (Weiss, 2012) morphological setting (Naylor et al., 2016) and boulder interactions/collisions (Knight and Burningham, 2011; Nandasena and Tanaka, 2013b).

Naylor et al. (2016) identified a limited relationshsip between transport distance and boulder mass and shape. Our data supports these findings whereby figures $17 \mathrm{a}$ and $17 \mathrm{~b}$ identify no significant relationship between boulder transport and mass $\left(\mathrm{r}^{2}\right.$ values of 0.01 and 0.03 at $B L$ and $B R$ respectively) or shape. This implies that boulder transport is not a direct function of these properties suggesting an alternative factor governs the extent to which transport occurs.

\section{The Role of the Morphological Setting}

Given the aforementioned limited relationship between boulder mass, shape and transport we considered the morphological pre-transport boulder setting as a factor in controlling clast displacement. Data presented in Table IV and Figures 12a and 12b

suggests a clearer relationship between clast displacement and the morphological setting of the tagged boulders. 


\section{Morphological setting 1 (MS1): incorporating MS1/4.}

Boulders assigned to MS1 were generally moved only short distances owing to the impediment of the platform edge. Only one boulder (tag ID: 1140) at BL was translocated from a constrained setting (MS1) to an unconstrained setting (MS4) on the platform surface. Although originally constrained by the platform edge, wave activity initiated incremental movements prior to storm conditions emplacing the clast on to and across the platform amounting to $10.6 \mathrm{~m}$ of transport, the boulder was known to have been overturned during transport. Subsequent wave activity when in an unconstrained setting (MS4) amounted to a further $2.6 \mathrm{~m}$ of transport. Collectively, MS1 clasts amounted to just $6 \%$ (14.6 m) of study total transport $(233.0 \mathrm{~m})$, the lowest of all MS's.

\section{Morphological setting 2 (MS2): incorporating MS2/3.}

Transport of boulders classified within MS2 related to incidents of block detachment from the platform edge. Three incidents of wave quarrying were recorded at BL, Figure

15. Once detachment occurred, subsequent wave action provided a sufficient lift force to elevate the boulders on to the shore platform. Quarried boulders (ID1127*, ID1134 and ID1148*) were displaced $7.2 \mathrm{~m}^{*}, 14.3 \mathrm{~m}$ and $15.0 \mathrm{~m}^{*}$ respectively; (ID* identifies boulders as being overturned during transport).

Despite the limited number of quarried boulders $(n=3)$ the examples provided indicate that following clast detachment from a joint-bound setting transport distances were considerable when compared with displacement from other MS's, $7.4 \mathrm{~m}$ per transport event compared with $0.7 \mathrm{~m}$ (MS1), $0.4 \mathrm{~m}$ (MS3) and $1.6 \mathrm{~m}$ (MS4). The total transport distance attributed to quarried boulders equates to $36.9 \mathrm{~m}, 16 \%$ of the study total from just $3 \%$ of the recorded transport events. Although the number of quarrying events is 
insignificant, the associated displacement is considerable. It also suggests the platform edge at $\mathrm{BL}$ is actively eroding. By contrast, quarrying was not recorded at $\mathrm{BR}$.

\section{Morphological setting 3 (MS3).}

Although recorded transport events were frequent, clast mobility was impeded by morphological features including raised scarps, intertidal pools, the gravel beach at BL and the boulder beach and berm at BR. This resulted in small incremental displacements, only $12 \%$ of MS3 transport incidents exceeded $0.5 \mathrm{~m}$. By comparison, $60 \%$ of MS4 transport events were $\geq 0.5 \mathrm{~m}$. The restricted displacement of MS3 boulders is further reflected in the transport values; $13 \%$ of the study transport total from $38 \%$ of the transport events producing the lowest mean distance per transport event, $0.4 \mathrm{~m}$. Notably, $53 \%$ of the boulders that failed to move during the study were assigned to MS3.

\section{Morphological setting 4 (MS4): incorporating MS4/3.}

MS4 boulders constitute $65 \%$ ( $57 \%$ at BL, $81 \%$ at BR) of the study total transport from $49 \%$ of the transport events, producing a mean distance per event of $1.6 \mathrm{~m}$. Figures $12 \mathrm{a}$ and $12 \mathrm{~b}$ indicate a preponderance of displaced MS4 and MS4/3 boulders. Significantly, they also highlight that subsequent to episodes of mobility, those MS4 clasts translocated to a constrained setting (MS4/3) were limited in their ability to be further displaced, as evidenced by the respective suffix values. This supports the findings of Naylor et al. (2016) who suggest the post-transport morphological setting also exerts limitations on boulder displacement.

The findings indicate, and support our hypothesis, that collectively unconstrained boulders (MS4) were transported further and more frequently than those in 
constrained settings (MS1, MS2 and MS3). However, individual constrained clasts liberated from a joint-bound setting (MS2) were transported further during the initial detachment phase.

A series of Mann-Whitney tests were conducted to determine whether a statistically significant difference existed between boulder transport distances and the morphological setting, (constrained/unconstrained). This was carried out for BL, BR and $B L$ and BR collectively $(\alpha=0.05)$. The test was conducted with and without nonmobile boulders (excluding non-movers), Table V.

Statistical analysis highlights the significance of the morphological setting in facilitating boulder transport. The distance over which constrained and unconstrained boulders are mobilised is significantly different at both sites, $p$-value's $\leq 0.05$. The median values also highlight the difference in transport distances attributed to unconstrained/constrained boulders. We therefore assert that the extent to which a boulder is displaced is significantly affected by the pre, and post morphological setting.

This data also validates the findings of Naylor et al. (2016) who identified geomorphic platform features including mass boulder assemblages and topographic irregularities as impediments to transport.

Aside from the aforementioned factors affecting transport there is an additional spatial component that requires consideration. At $\mathrm{BL}$ the mixed sand and gravel beach at the rear of the platform is the main geomorphic obstacle impeding boulder transport. Platform width, measured from the platform terminus to the beach ranges from $5 \mathrm{~m}$ to $55 \mathrm{~m}$. At BR landward transport is impeded by the boulder beach and berm; platform width from the seaward terminus to these features ranges from $15 \mathrm{~m}$ to $40 \mathrm{~m}$. While both landforms restrict displacement, the available distance across which transport 
can occur prior to encountering such an obstacle is greater at BL than at BR. Hence, the larger recorded transport distances.

\section{Mode of transport}

Despite the growing interest in boulder transport studies there remains limited quantitative evidence regarding transport modes during entrainment and displacement (Paris et al, 2011; Goto et al., 2011, Naylor et al., 2016). Incorporating the orientation hole to each tagged boulder provides insight to transport mechanisms during episodes of mobility. Those clasts found with the orientation hole below the embedded RFID tag were known to have been overturned at least once during entrainment and/or transport. Of the 195 transport events recorded, 13\% ( $n=26, \mathrm{BL}: 12$ and BR: 14$)$ resulted in overturning. Such incidents at BL accounted for $46 \%(69.7 \mathrm{~m})$ of the total transport, the mean overturning transport distance was $5.8 \mathrm{~m}$, the maximum was 16.1 m. At BR overturning accounted for $24 \%(19.6 \mathrm{~m})$ of the total transport at the site, producing a mean overturning transport distance $1.4 \mathrm{~m}$, the maximum was $6.4 \mathrm{~m}$. Collectively, $38 \%(89.3 \mathrm{~m})$ of the transport total was attributed to overturning, consequently, $62 \%$ to displacement by sliding. The data demonstrates, with fieldbased evidence, that overturning of boulders weighing up to $5 \mathrm{t}$ is possible during high frequency, low magnitude storm events. Furthermore, it affirms the assertion that overturning results in greater transport distances than sliding (Imamura et al., 2008) and confirms the findings of Nandasena and Takana (2013b), Zainali and Weiss (2015) and Noormets et al. (2004) who applied numerical modelling to establish sliding as the more dominant mode of transport. 


\section{Wave climate and tidal regime}

Transport and wave data indicate that increased wave magnitude does not always correspond with greater transport distance. To illustrate this Table VI presents a summary of transport and wave parameters relating to two consecutive survey periods at BL. The transport distances associated with the period between 23 September and 25 November 2016 coincided with Storm Angus (20 November 2016) when the largest wave height $\left(\mathrm{H}_{\mathrm{s}}\right)$ of the study was recorded, $\mathrm{H}_{\mathrm{s}}=2.3 \mathrm{~m}$ at Sandown Pier.

The data identifies the greater transport distance is attributed to the latter survey period despite the reduced storm wave activity. The key difference between the two event periods is the direction of storm wave approach relative to the aspect of the shore platform. Wave activity associated with Storm Angus occurred from a SSE direction $\left(154^{\circ}\right)$ opposed to the ESE $\left(115^{\circ}\right)$ as was the case with the weaker storm event. It is proposed that the ESE wave direction had a greater transport potential on the east-facing platform of BL than the more southerly wave activity. This suggests that wave magnitude alone is not a reliable or accurate indicator of boulder transport potential (Kennedy et al., 2019) and other factors including storm wave direction relative to the coastal aspect require consideration.

The extent to which transport of coarse and very coarse clasts occurred under low to moderate storm wave activity was unexpected. The transport data identified the three largest mobile clasts, as defined by mass, were all located at BR - estimated mass, $2.4 \mathrm{t}$ - tag ID: 1189; $5.0 \mathrm{t}-\operatorname{tag}$ ID: $1187^{*}$ and $11.9 \mathrm{t}-\operatorname{tag}$ ID: $1188 ;{ }^{*} \operatorname{tag}$ ID: 1187 was overturned twice during the study). During the study the three boulders were displaced $2.6 \mathrm{~m}, 9.8 \mathrm{~m}$ and $3.6 \mathrm{~m}$ respectively, totalling $16.0 \mathrm{~m}$. The majority of transport $(93 \%)$ occurred between 19 February - 31 May 2016 which coincided with Storm Katie (27 - 
28 March 2016) and 1 September - 9 December 2016 which coincided with Storm Angus (19 - 22 November 2016). The inshore wave and tidal data was consulted to better understand the hydrodynamic conditions that we assert facilitated displacement of these clasts. Wave parameters $\left(\mathrm{H}_{\mathrm{s}}\right.$ and $\left.\mathrm{H}_{\max }\right)$ and the corresponding tidal state at the peak of Storms Katie and Angus are presented in Figures 18a and 18b. The CCO storm threshold $(1.6 \mathrm{~m})$ is included to indicate the extent to which the threshold was exceeded.

The inshore $\mathrm{H}_{\mathrm{s}}$ wave values peaked during Storm Katie and Angus at $1.9 \mathrm{~m}$ and 2.3 m respectively, whilst peak $H_{\max }$ values were $2.3 \mathrm{~m}$ and $2.9 \mathrm{~m}$. Notably, peak storm wave activity occurred at, or shortly after high water suggesting that storm and tidal state relative to boulder elevation may be significant in mobilising the largest boulders (Stephenson et al., 2018).

\section{Broader geomorphic modification}

The RFID transport data presented herein demonstrates the occurrence of individual boulder mobility under low to moderate storm wave activity. However, further field evidence of geomorphic alteration was observed which suggested storm waves were capable of mass boulder movement. This was manifest in the displacement of multiple clasts within the boulder berm at BR following storm activity; the boulder berm is identified in Figures 3 and 9. Aerial imagery from the CCO was used to confirm whether mass movement of the berm had occurred under contemporary storm conditions.

Periodic images were processed in ArcGIS (vers. 10.5) and the seaward extent of the berm was highlighted on the available image data, this was subsequently overlaid for comparative purposes (Figure 19).

This article is protected by copyright. All rights reserved. 
The findings identified that between 2005 and 2013 movement of the berm edge was limited to minor shifts, most likely arising from the supplanting of individual boulders. However, during the period 2013 to 2016 the seaward margin of the boulder berm moved over $7 \mathrm{~m}$ landward in some areas. The 2013 data was obtained in August, prior to the winter period of 2013 - 2014, which was dominated by a series of low-pressure storm fronts that reportedly made this the stormiest winter on record (Matthews et al., 2014; Masselink et al., 2016). Nearshore wave heights at the Sandown Bay wave monitoring station registered a maximum $\mathrm{H}_{\mathrm{s}}$ of $3.5 \mathrm{~m}$ and a $\mathrm{H}_{\max }$ of $5.9 \mathrm{~m}$ over the 2013 - 2014 winter period. The highest values recorded since wave monitoring commenced at the location in 2006.

This establishes moderate contemporary storm waves as an agent of mass boulder displacement resulting in the modification of sizable geomorphic features. Thus, storm activity at Bembridge initiates geomorphic change on a larger-scale than had previously been realised. This reinforces the findings of Pérez-Alberti and Trenhaile, (2015), Gómez-Pazo et al. (2019) and Nagle-McNaughton and Cox, (2020) who documented widespread, collective mass movement of detached clasts using Unmanned Aerial Vehicles (UAV's).

It was initially considered that the close proximity of the two study sites would enable comparisons to be drawn between locations. However, despite geological and climatic similarities there are a host of additional factors that differ such as lithology, topography, morphological features, shore platform exposure and aspect. Such fundamental differences make direct comparisons between sites problematic, as demonstrated by the disparity between transport distances and the varying responses to the same storm events. Whilst similarities exist between what may be considered 
'comparable settings' the range and complexity of the underlying transport processes and mechanisms and the degree to which they apply at any given location means universal theories governing boulder transport should be applied with caution.

\section{Conclusion}

This study represents the first long-term intertidal boulder transport monitoring programme of its kind. Favourable tag recovery rates (92\% on completion) identified $69 \%$ of the RFID tagged boulders were transported $233.0 \mathrm{~m}$, predominantly by means of sliding, although incidents of overturning were also identified. The findings provide

a wealth of quantifiable transport data which presents compelling evidence that incidents of boulder detachment, overturning and displacement are not confined to extreme, infrequent, high magnitude storm events. On the contrary, low magnitude, high frequency storm waves are shown to be effective agents of erosion, transport and macro-scale geomorphic modification on this relatively sheltered intertidal rocky coast.

The data identifies the pre-, and post-transport morphological setting as a significant factor in facilitating, and impeding boulder transport. The limited displacement of clasts in constrained morphological settings supports the notion that geomorphic platform features represent significant barriers to clast mobility (Trenhaile, 2016; Naylor et al., 2016; Hastewell et al., 2019a).

We affirm that boulder transport is governed by a host of complex interactions including, but not limited to:

(a) site-specific characteristics: platform morphology and topography, boulder location relative to morphological features, litho-structure of the boulder producing units, aspect relative to storm wave approach, and; 
(b) hydrodynamic conditions: tidal state, storm wave magnitude and direction.

The longevity of the tags operational capacity ( 4 years to date) allows for the prolonged assessment of storm activity and the associated boulder transport responses to be determined. We therefore suggest further deployments of RFID tagged boulders across a range of coastal settings from low/moderate wave climates to those exposed to extreme cyclone/hurricane generated storms. Furthermore, the method may prove advantageous in coastal areas where debate exists over whether boulders have, or have not been displaced (Cox, 2019), or where the transport mode is contested (Morton et al., 2008; Barbano et al., 2010; Dewey and Ryan, 2017). Such deployments will provide an opportunity to better understand wave competence in terms of boulder transport and conceivably, elucidate the enduring storm and/or tsunami wave conundrum.

An improved awareness of the capabilities of contemporary storm events will further enhance our understanding of the responsiveness of rocky coasts in a changing global climate. Improved understanding of the response mechanisms will be critical in accurately assessing coastal vulnerability and risk and mitigating against future storm wave hazards. It is anticipated that this data will better inform policymakers tasked with adaptive planning aimed at improving resilience and safeguarding coastal populations, infrastructure and natural capital.

Acknowledgements - The field work component of this research study was financially supported by the British Society for Geomorphology and the Royal Geographical Society. The authors wish to thank the reviewers for their constructive comments, which greatly improved the manuscript. Finally, we extend our gratitude to those that 
willingly provided assistance in the field. The authors declare there are no conflicts of interest with regard to this research.

\section{Data availability statement}

Research data not shared

\section{References}

Allan JC, Hart R, Tranquili JV. 2006. The use of Passive Integrated Transponder (PIT) tags to trace cobble transport in a mixed sand-and gravel beach on the high-energy Oregon coast, USA. Marine Geology 232: 63-86. DOI:org/10.1016/j.margeo.2006.07.005.

Almeida LP, Masselink G, Russell PE, Davidson MA. 2015. Observations of gravel beach dynamics during high energy wave conditions using a laser scanner. Geomorphology 228: 15-27. DOI:org/10.1016/j.geomorph.2014.08.019

Armenteros I, Daley B. 1998. Pedogenic modification and structure evolution in palustrine facies as exemplified by the Bembridge Limestone (Late Eocene) of the Isle of Wight, southern England. Sedimentary Geology 119(3): 275-295. DOI:org/10.1016/S0037-0738(98)00067-0.

Autret R, Dodet G, Fichaut B, Suanez S, David L, Leckler F, Ardhuin F, Ammann J, Grandjean P, Allemand P, Filipot JF. 2016. A comprehensive hydro-geomorphic study of cliff-top storm deposits on Banneg Island during winter 2013-2014. Marine Geology 382: 37-55. DOI:org/10.1016/j.margeo.2016.09.014. 
Autret R, Dodet G, Suanez S, Roudaut G, Fichaut B. 2018. Long-term variability of supratidal coastal boulder activation in Brittany (France). Geomorphology 304: 184200. DOI:org/10.1016/j.geomorph.2017.12.028.

Barbano MS, Pirrotta C, Gerardi F. 2010. Large boulders along the south-eastern Ionian coast of Sicily: Storm or tsunami deposits?. Marine Geology, 275(1): 140-154. DOI: org/10.1016/j.margeo.2010.05.005

Beniston M, Stephenson DB, Christensen OB, Ferro CA, Frei C, Goyette S, Halsnaes K, Holt T, Jylhä K, Koffi B, Palutikof J. 2007. Future extreme events in European climate: an exploration of regional climate model projections. Climatic Change 81(1): 71-95. DOI:org/10.1007/s10584-006-9226-z.

Biolchi S, Furlani S, Devoto S, Scicchitano G, Korbar T, Vilibić I, Šepić, J. 2019a. The origin and dynamics of coastal boulders in a semi-enclosed shallow basin: A northern $\begin{array}{lllll}\text { Adriatic } & \text { case } & \text { study. Marine } & \text { Geology } & \text { 411: }\end{array}$ DOI:org/10.1016/j.margeo.2019.01.008

Biolchi S, Denamiel C, Devoto S, Korbar T, Macovaz V, Scicchitano G, Vilibić I, Furlani S. 2019b. Impact of the October 2018 Storm Vaia on Coastal Boulders in the Northern Adriatic Sea. Water, 11(11), 2229. DOI:org/10.3390/w11112229

Blair TC, McPherson JG. 1999. Grain-size and textural classification of coarse sedimentary particles. Journal of Sedimentary Research 69(1): 6-19.

Bray MJ, Workman M, Smith J, Pope D. 1996. Field measurements of shingle transport using electronic tracers. In Proceedings of the $31^{\text {st }}$ MAFF Conference River and Coastal Engineers, Vol. 1996; 10-14. 
Brayne RP. 2015. The Relationship between Nearshore Wave Conditions and Coarse Clastic Beach Dynamics. Unpublished PhD thesis, Exeter University.

Buchanan DH, Naylor LA, Hurst MD, Stephenson WJ. (2020) Erosion of rocky shore platforms by block detachment from layered stratigraphy. Earth Surface Processes and Landforms.

Buscombe D, Masselink G. 2006. Concepts in gravel beach dynamics. Earth-Science Reviews 79(1-2): 33-52. DOI:org/10.1016/j.earscirev.2006.06.003

Casamayor M, Alonso I, Cabrera J, Rodríguez S, Sánchez-García MJ. 2015. Long term recovery rates obtained using RFID technology at a mixed beach. Geologica Acta 13(2): 85-96.

Channel Coast Observatory (CCO). 2015. Annual Wave Report 2015 Sandown Bay. Available at: http://www.channelcoast.org/reports/ [Accessed: 30 August 2018].

Channel Coast Observatory (CCO). 2018. Wave data Sandown Pier. Available at: http://www.channelcoast.org/data_management/online_data_catalogue/ [Accessed: 2 October 2018].

Chapuis M, Bright CJ, Hufnagel J, MacVicar B. (2014). Detection ranges and uncertainty of passive Radio Frequency Identification (RFID) transponders for sediment tracking in gravel rivers and coastal environments. Earth Surface Processes and Landforms 39(15): 2109-2120. DOI:org/10.1002/esp.3620

Cox R, Jahn KL, Watkins OG, Cox P. 2018. Extraordinary boulder transport by storm waves (West of Ireland, winter 2013-2014), and criteria for analysing coastal boulder 
deposits.

Earth-Science

Reviews

177:

623-636.

DOI:org/10.1016/j.earscirev.2017.12.014

Cox R, Zentner DB, Kirchner BJ, Cook MS. 2012. Boulder ridges on the Aran Islands (Ireland): recent movements caused by storm waves, not tsunamis. The Journal of Geology 120(3): 249-272. DOI:org/10.1086/664787

Cruslock EM, Naylor LA, Foote YL, Swantesson JO. Geomorphologic equifinality. 2010. A comparison between shore platforms in Höga Kusten and Fårö, Sweden and the Vale of Glamorgan, South Wales, UK. Geomorphology 114(1-2):78-88. DOl:org/10.1016/j.geomorph.2009.02.019

Cullen ND, Bourke MC. 2018. Clast abrasion of a rock shore platform on the Atlantic coast of Ireland. Earth Surface Processes and Landforms, 43(12): 2627-2641. DOI: doi.org/10.1002/esp.4421

Dasgupta R. 2011. Whither shore platforms?. Progress in Physical Geography 35(2) 183-209. DOI:org/10.1177/0309133310375730

Dewey JF, Ryan PD. 2017. Storm, rogue wave, or tsunami origin for megaclast deposits in western Ireland and North Island, New Zealand?. Proceedings of the National Academy of Sciences, 114(50): E10639-E10647.

Dickson ME, Kench PS, Kantor MS. 2011. Longshore transport of cobbles on a mixed sand and gravel beach, southern Hawke Bay, New Zealand. Marine Geology 287(1): 31-42. DOI:org/10.1016/j.margeo.2011.06.009. 
Dolphin T, Lee J, Phillips R, Taylor CJ, Dyer KR. 2016. Velocity of RFID tagged gravel in a non-uniform longshore transport system. Journal of Coastal Research 75(sp1): 363-367. DOI:org/10.2112/SI75-073.1.

Engel M, May SM. 2012. Bonaire's boulder fields revisited: evidence for Holocene tsunami impact on the Leeward Antilles. Quaternary Science Reviews 54: 126-141. DOI:org/10.1016/j.quascirev.2011.12.011.

Etienne S, Buckley M, Paris R, Nandasena AK, Clark K, Strotz L, Chagué-Goff C, Goff J, Richmond B. 2011.The use of boulders for characterising past tsunamis: lessons from the 2004 Indian Ocean and 2009 South Pacific tsunamis. Earth-Science Reviews, 107(1-2): 76-90. DOI:org/10.1016/j.earscirev.2010.12.006

Etienne S, Paris R. 2010. Boulder accumulations related to storms on the south coast of the Reykjanes Peninsula (Iceland). Geomorphology 114(1-2): 55-70. DOI:org/10.1016/j.geomorph.2009.02.008

Fichaut B, Suanez S. 2011. Quarrying, transport and deposition of clifftop storm deposits during extreme events: Banneg Island, Brittany. Marine Geology 283(1): 3655. DOI:org/10.1016/j.margeo.2010.11.003.

Furlani S, Biolchi S, Devoto S, Saliba D, Scicchitano G. 2011. Large Boulder Along the NE Maltese Coast: Tsunami or Storm Wave Deposits?. Journal of Coastal Research 61: 470. DOI:org/10.2112/SI61-001.60

Gómez-Pazo A, Pérez-Alberti A, Trenhaile, A. 2019. Recording inter-annual changes on a boulder beach in Galicia, NW Spain using an unmanned aerial vehicle. Earth Surface Processes and Landforms 44(5): 1004-1014. DOI:org/10.1002/esp.4549 
Goto K, Kawana T, Imamura F. 2010a. Historical and geological evidence of boulders deposited by tsunamis, southern Ryukyu Islands, Japan. Earth-Science Reviews 102(1-2): 77-99. DOI:org/10.1016/j.earscirev.2010.06.005

Goto K, Miyagi K, Kawamata H, Imamura F. 2010b. Discrimination of boulders deposited by tsunamis and storm waves at Ishigaki Island, Japan. Marine Geology 269(1-2): 34-45. DOI:org/10.1016/j.margeo.2009.12.004

Goto K, Miyagi K, Kawana T, Takahashi J, Imamura F. 2011. Emplacement and movement of boulders by known storm waves-field evidence from the Okinawa Islands, Japan. Marine Geology 283(1-4): 66-78.

DOl.org/10.1016/j.margeo.2010.09.007.

Goto K, Okada K, Imamura F. 2009. Characteristics and hydrodynamics of boulders transported by storm waves at Kudaka Island, Japan. Marine Geology 262(1-4): 1424. DOI:org/10.1016/j.margeo.2009.03.001.

Hall AM, Hansom JD, Jarvis J. 2008. Patterns and rates of erosion produced by high energy wave processes on hard rock headlands: The Grind of the Navir, Shetland, Scotland. Marine Geology 248(1-2): 28-46. DOI:org/10.1016/j.margeo.2007.10.007

Hall AM, Hansom JD, Williams DM, Jarvis J. 2006. Distribution, geomorphology and lithofacies of cliff-top storm deposits: Examples from the high-energy coasts of Scotland and Ireland. Marine Geology 232(3-4): 131-155. DOI: org/10.1016/j.margeo.2006.06.008

Han M, Yang DY, Yu J, Kim JW. 2017. Typhoon impact on a pure gravel beach as assessed through gravel movement and topographic change at Yeocha beach, South 
Coast of Korea. Journal of Coastal Research 33(4): 889-906. DOI:org/10.2112/JCOASTRES-D-16-00104.1.

Hansom JD, Hall AM. 2009. Magnitude and frequency of extra-tropical North Atlantic cyclones: a chronology from cliff-top storm deposits. Quaternary International 195(12): 42-52. DOI:org/10.1016/j.quaint.2007.11.010

Hastewell LJ, Schaefer M, Bray M, Inkpen R. 2019a. Intertidal boulder transport: A proposed methodology adopting Radio Frequency Identification (RFID) technology to quantify storm induced boulder mobility. Earth Surface Processes and Landforms 44(3): 681-698. DOI:org/10.1002/esp.4523

Hastewell L, Inkpen R, Bray M. 2019b. Identification of plate-forme à vasques on a temperate shore platform? Quantitative analysis of morphology and relationships at Bembridge, Isle of Wight. Zeitschrift für Geomorphologie 62(2): 145-162. DOl:org/10.1127/zfg/2019/0600

Héquette A, Cartier A. 2016. Theoretical and observed breaking wave height on a barred macrotidal beach: implications for the estimation of breaker index on beaches with large tidal range. Journal of Coastal Research 75(1): 861-866.

Herterich JG, Cox R, Dias F. 2018. How does wave impact generate large boulders? Modelling hydraulic fracture of cliffs and shore platforms. Marine Geology 399: 34-46. DOI:org/10.1016/j.margeo.2018.01.003

Hills ES. 1972. Shore platforms and wave ramps. Geological Magazine 109(2): 81-88. DOI:org/10.1017/S0016756800039479 
Imamura F, Goto K, Ohkubo S. 2008. A numerical model for the transport of a boulder by tsunami. Journal of Geophysical Research, Oceans 113(C1). DOI:org/10.1029/2007JC004170.

Insole AN, Daley B, Gale A. 1998. The Isle of Wight (No. 60). Geologists' Association.

Kennedy DM. 2010. Geological control on the morphology of estuarine shore platforms: Middle Harbour, Sydney, Australia. Geomorphology 114(1-2): 71-77. DOI: org/10.1016/j.geomorph.2009.02.012

Kennedy AB, Mori N, Yasuda T, Shimozono T, Tomiczek T, Donahue A, Shimura T, Imai Y. 2017. Extreme block and boulder transport along a cliffed coastline (Calicoan Island, Philippines) during Super Typhoon Haiyan. Marine Geology 383: 65-77. DOI: i.org/10.1016/j.margeo.2016.11.004

Kennedy DM, Woods JL, Naylor LA, Hansom JD, Rosser NJ. 2019. Intertidal boulderbased wave hindcasting can underestimate wave size: Evidence from Yorkshire, UK. Marine Geology 411: 98-106. DOI: org/10.1016/j.margeo.2019.02.002

Knight J, Burningham H. 2011. Boulder dynamics on an Atlantic-facing rock coastline, northwest Ireland. Marine Geology 283(1-4): 56-65.

DOI:org/10.1016/j.margeo.2010.07.008

Knight J, Burningham H, Barrett-Mold C. 2009. The geomorphology and controls on development of a boulder-strewn rock platform, NW Ireland. Journal of Coastal Research 56: 1646-1650. 
Kogure T, Aoki H, Maekado A, Hirose T, Matsukura Y. 2006. Effect of the development of notches and tension cracks on instability of limestone coastal cliffs in the Ryukyus, Japan. Geomorphology 80(3-4): 236-244. DOI:org/10.1016/j.geomorph.2006.02.012 Lau AA, Terry JP, Ziegler AD, Switzer AD, Lee Y, Etienne S. 2016. Understanding the history of extreme wave events in the Tuamotu Archipelago of French Polynesia from large carbonate boulders on Makemo Atoll, with implications for future threats in the $\begin{array}{llll}\text { central South } & \text { Pacific. } & \text { 174-90. }\end{array}$ DOI:org/10.1016/j.margeo.2016.04.018

Leckebusch GC, Koffi B, Ulbrich U, Pinto JG, Spangehl T, Zacharias S. 2006. Analysis of frequency and intensity of European winter storm events from a multi-model perspective, at synoptic and regional scales. Climate Research 31(1): 59-74. DOI:10.3354/cr031059

Lee MW, Bray M, Workman M, Collins MB, Pope D. 2000. Coastal shingle tracing: a case study using the 'Electronic Tracer System’ (ETS). In Tracers in Geomorphology, Watson IDL (ed). Wiley: Chichester; 413-435.

Long D. 2017. Cataloguing tsunami events in the UK. Geological Society, London, Special Publications 456(1): 143-165. DOI:org/10.1144/SP456.10

Maouche S, Morhange C, Meghraoui M. 2009. Large boulder accumulation on the Algerian coast evidence tsunami events in the western Mediterranean. Marine Geology 262(1-4): 96-104. DOI:org/10.1016/j.margeo.2009.03.013

Masselink G, Castelle B, Scott T, Dodet G, Suanez S, Jackson D, Floc'h F. (2016). Extreme wave activity during 2013/2014 winter and morphological impacts along the 
Atlantic coast of Europe. Geophysical Research Letters 43(5): 2135-43. DOI:10.1002/2015GL067492

Mastronuzzi G, Sansò P. 2000. Boulders transport by catastrophic waves along the Ionian coast of Apulia (southern Italy). Marine Geology 170(1-2): 93-103. DOI:org/10.1016/S0025-3227(00)00068-2

Matthews T, Murphy C, Wilby RL, Harrigan S. (2014). Stormiest winter on record for Ireland and UK. Nature Climate Change 4(9), 738.

McKenna J. 2005. Boulder beaches. In Encyclopaedia of Coastal Science (pp. 206208). Schwartz, M. (Ed.). Springer Science \& Business Media, Kluwer, Dordrecht.

McKenna J, Jackson DW, Cooper JAG. 2011. In situ exhumation from bedrock of large rounded boulders at the Giant's Causeway, Northern Ireland: An alternative genesis for large shore boulders (mega-clasts). Marine Geology 283(1-4): 25-35. DOI:org/10.1016/j.margeo.2010.09.005

Miller IM, Warrick JA, Morgan C. 2011. Observations of coarse sediment movements on the mixed beach of the Elwha Delta, Washington. Marine Geology 282(3): 201-214. DOI:org/10.1016/j.margeo.2011.02.012.

Mottershead D, Bray M, Soar P, Farres PJ. 2014. Extreme wave events in the central Mediterranean: geomorphic evidence of tsunami on the Maltese Islands. Zeitschrift für Geomorphologie 58(3): 385-411. DOI:org/10.1127/0372-8854/2014/0129.

Nagle-McNaughton T, Cox R. 2020. Measuring Change Using Quantitative Differencing of Repeat Structure-From-Motion Photogrammetry: The Effect of Storms on Coastal Boulder Deposits. Remote Sensing 12(1): 42. 
Nandasena NAK, Paris R, Tanaka N. 2011. Reassessment of hydrodynamic equations: minimum flow velocity to initiate boulder transport by high energy events (storms, tsunamis).

Marine

Geology

281(1):

70-84.

DOl:org/10.1016/j.margeo.2011.02.005.

Nandasena NAK, Tanaka N. 2013a. Boulder transport by high-energy (tsunamis): Model development for threshold entrainment and transport. Research Report of Department of Civil and Environmental Engineering, Saitama Univ, 39(1): 1-12.

Nandasena NAK, Tanaka N. 2013b. Boulder transport by high energy: Numerical model-fitting experimental observations. Ocean Engineering 57: 163-179. DOI: .org/10.1016/j.oceaneng.2012.09.012

Naylor LA, Stephenson WJ. 2010. On the role of discontinuities in mediating shore platform erosion. Geomorphology 114(1-2):

89-100.

DOI:org/10.1016/j.geomorph.2008.12.024

Naylor LA, Stephenson WJ, Smith HC, Way O, Mendelssohn J, Cowley A. 2016. Geomorphological control on boulder transport and coastal erosion before, during and after an extreme extra-tropical cyclone. Earth Surface Processes and Landforms 41(5): 685-700. DOl:org/10.1002/esp.3900

Nichols $\mathrm{MH}$. 2004. A radio frequency identification system for monitoring coarse sediment particle displacement. Applied Engineering in Agriculture 20(6): 783-787. DOI:org/10.13031/2013.17727.

Noormets R, Crook KA, Felton EA. 2004. Sedimentology of rocky shorelines: 3. Hydrodynamics of megaclast emplacement and transport on a shore platform, Oahu, 
DOI:org/10.1016/j.sedgeo.2004.07.006

Nott J. 2003. Waves, coastal boulder deposits and the importance of the pre-transport setting. Earth and Planetary Science Letters 210(1-2): 269-276. DOI: 10.1016/S0012$821 \times(03) 00104-3$

Ogawa H, Dickson ME, Kench PS. 2011. Wave transformation on a sub-horizontal shore platform, Tatapouri, North Island, New Zealand. Continental Shelf Research 31(14): 1409-1419. DOI:org/10.1016/j.csr.2011.05.006

Oregon RFID. 2017. HDX Long Range Readers [Online]. Available at: https://www.oregonrfid.com/index.php?main_page=product_info\&cPath=1\&products _id=6\&zenid=osn1jj|3mico7k819j0q5n3ho5 [Accessed: 12 September 2017].

Paris R, Naylor LA, Stephenson WJ. 2011. Boulders as a signature of storms on rock coasts. Marine Geology 283(1-4): 1-11. DOI:org/10.1016/j.margeo.2011.03.016.

Pérez-Alberti A, Trenhaile AS. 2015. Clast mobility within boulder beaches over two winters in Galicia, northwestern Spain. Geomorphology 248: 411-426. DOI:org/10.1016/j.geomorph.2015.08.001

Roig-Munar FX, Rodríguez-Perea A, Vilaplana JM, Martín-Prieto JA, Gelabert B. 2019. Tsunami boulders in Majorca Island (Balearic Islands, Spain). Geomorphology 334: 76-90. DOI:org/10.1016/j.geomorph.2019.02.012

Salzmann L, Green A. 2012. Boulder emplacement on a tectonically stable, wavedominated coastline, Mission Rocks, northern KwaZulu-Natal, South Africa. Marine Geology 323: 95-106. DOI:org/10.1016/j.margeo.2012.07.001 
Scheffers A. Scheffers S. 2006. Documentation of the impact of Hurricane Ivan on the coastline of Bonaire (Netherlands Antilles). Journal of Coastal Research 22(6): 14371450. DOI:org/10.2112/05-0535.1

Scheffers A, Scheffers S, Kelletat D, Browne T. 2009. Wave-emplaced coarse debris and megaclasts in Ireland and Scotland: boulder transport in a high-energy littoral environment. The Journal of Geology 117(5): 553-573. DOI:org/10.1086/600865.

Scicchitano G, Monaco C, Tortorici L. 2007. Large boulder deposits by tsunami waves along the lonian coast of south-eastern Sicily (Italy). Marine Geology 238(1-4): 75-91. DOI:org/10.1016/j.margeo.2006.12.005

Sear DA, Lee MW, Oakley RJ, Carling PA, Collins MB. 2000. Coarse sediment tracing technology in littoral and fluvial environments: a review. In Tracers in Geomorphology, Watson IDL (ed). Wiley: Chichester; 21-55.

Shah-hosseini M, Morhange C, Beni AN, Marriner N, Lahijani H, Hamzeh M, Sabatier F. 2011. Coastal boulders as evidence for high-energy waves on the Iranian coast of Makran. Marine Geology 290(1): 17-28. DOI:org/10.1016/j.margeo.2011.10.003.

Spiske M, Bahlburg H. 2011. A quasi-experimental setting of coarse clast transport by the 2010 Chile tsunami (Bucalemu, Central Chile). Marine Geology 289(1-4): 72-85. DOI:org/10.1016/j.margeo.2011.09.007.

Stephenson WJ, Kirk RM. 2000. Development of shore platforms on Kaikoura Peninsula, South Island, New Zealand. Part one: the role of waves. Geomorphology 32(1-2): 21-41. DOI:org/10.1016/S0169-555X(99)00061-6 
Stephenson WJ, Naylor LA. 2011.Geological controls on boulder production in a rock coast setting: insights from SouthWales, UK. Marine Geology 283(1): 12-24. DOI:org/10.1016/j.margeo.2010.07.001.

Stephenson WJ, Naylor LA, Smith H, Chen B, Brayne RP. 2018. Wave transformation across a macrotidal shore platform under low to moderate energy conditions. Earth Surface Processes and Landforms 43(1): 298-311. DOI: doi.org/10.1002/esp.4245.

Sunamura T. 1992. Geomorphology of Rocky Coasts, Vol. 3. John Wiley \& Sons: Chichester.

Switzer AD, Burston JM. 2010. Competing mechanisms for boulder deposition on the southeast Australian coast. Geomorphology 114(1-2): 42-54. DOI:org/10.1016/j.geomorph.2009.02.009.

Terry JP, Dunne K, Jankaew K. 2016. Prehistorical frequency of high-energy marine inundation events driven by typhoons in the Bay of Bangkok (Thailand), interpreted from coastal carbonate boulders. Earth Surface Processes and Landforms 41(4): 553562. DOI:org/10.1002/esp.3873

Terry JP, Lau AA. 2018. Magnitudes of nearshore waves generated by tropical cyclone Winston, the strongest landfalling cyclone in South Pacific records. Unprecedented or unremarkable?. Sedimentary Geology 364: 276-285.

DOI: org/10.1016/j.sedgeo.2017.10.009

Topcon. 2018. HiPer V - Topcon Positioning Systems, Inc. [Online]. Available at: https://www.topconpositioning.com/sites/default/files/product_files/hiper_v_broch_70 10_2121_reve_sm.pdf [Accessed: 14 December 2018]. 
Trenhaile, A. S. (1987). The geomorphology of rock coasts. Oxford University Press, USA.

Trenhaile AS. 2015. Coastal notches: their morphology, formation, and function. EarthScience Reviews 150: 285-304. DOI:org/10.1016/j.earscirev.2015.08.003

Trenhaile AS. 2016. Rocky coasts - their role as depositional environments. EarthScience Reviews 159: 1-13. DOI:org/10.1016/j.earscirev.2016.05.001.

Trenhaile AS. 2019. Hard-Rock Coastal Modelling: Past Practice and Future Prospects in a Changing World. Journal of Marine Science and Engineering 7(2), 34. DOI:org/10.3390/jmse7020034

Trenhaile AS, Kanyaya JI. 2007. The role of wave erosion on sloping and horizontal shore platforms in macro-and mesotidal environments. Journal of Coastal Research 23(2): 298-309. DOI: org/10.2112/04-0282.1

Weiss R. 2012. The mystery of boulders moved by tsunamis and storms. Marine Geology 295: 28-33. DOI:org/10.1016/j.margeo.2011.12.001

Williams DM, Hall AM. 2004. Cliff-top megaclast deposits of Ireland, a record of extreme waves in the North Atlantic-storms or tsunamis?. Marine Geology 206(1-4): 101-117. DOI: org/10.1016/j.margeo.2004.02.002

Zainali A, Weiss R. 2015. Boulder dislodgement and transport by solitary waves: Insights from three-dimensional numerical simulations. Geophysical Research Letters 42(11): 4490-4497. DOI:org/10.1002/2015GL063712

Zingg T. 1935. Beitrag zur Schotteranalyse. Schweizerische Mineralogische und Petrographische Mitteilungen 15: 39-140. DOI:org/10.3929/ethz-a-000103455. 
Table I. Tag deployment, boulder relocation survey dates and time elapsed (days) between surveys at $B L$ and $B R$.

\begin{tabular}{|c|c|c|c|c|}
\hline $\begin{array}{l}\text { BEMBRIDGE } \\
\text { LEDGE }\end{array}$ & Survey no. & Survey date (from) & Survey date (to) & $\begin{array}{c}\text { Interval between surveys } \\
\text { (no. of days) }\end{array}$ \\
\hline \multirow{4}{*}{ Year 1} & S1 & 25 July $2015^{\star}$ & 03 February 2016 & 193 \\
\hline & S2 & 03 February 2016 & 17 February 2016 & 14 \\
\hline & S3 & 17 February 2016 & 01 April 2016 & 44 \\
\hline & S4 & 01 April 2016 & 23 September 2016 & 175 \\
\hline \multirow{3}{*}{ Year 2} & S5 & 23 September 2016 & 25 November 2016 & 63 \\
\hline & S6 & 25 November 2016 & 08 February 2017 & 75 \\
\hline & S7 & 08 February 2017 & 05 May 2017 & 86 \\
\hline Year 3 & S8 & 05 May 2017 & 10 May 2018 & 370 \\
\hline
\end{tabular}

\begin{tabular}{|c|c|c|c|c|}
\hline $\begin{array}{l}\text { BLACK } \\
\text { ROCK }\end{array}$ & Survey no. & Survey date (from) & Survey date (to) & $\begin{array}{c}\text { Interval between surveys } \\
\text { (no. of days) }\end{array}$ \\
\hline \multirow{5}{*}{ Year 1} & S1 & 10 July $2015^{*}$ & 03 December 2015 & 146 \\
\hline & S2 & 03 December 2015 & 06 January 2016 & 34 \\
\hline & S3 & 06 January 2016 & 19 February 2016 & 44 \\
\hline & S4 & 19 February 2016 & 31 May 2016 & 102 \\
\hline & S5 & 31 May 2016 & 01 September 2016 & 93 \\
\hline \multirow{3}{*}{ Year 2} & S6 & 01 September 2016 & 09 December 2016 & 99 \\
\hline & s7 & 09 December 2016 & 22 February 2017 & 75 \\
\hline & S8 & 22 February 2017 & 24 May 2017 & 91 \\
\hline Year 3 & s9 & 24 May 2017 & 11 July 2018 & 352 \\
\hline
\end{tabular}

* - tag deployment date. 
Table II: Bembridge Ledge - summary of individual boulder characteristics, distance $(\mathrm{m})$ and direction $\left(^{\circ}\right)$ of transported boulders between specified survey periods. Cumulative survey transport totals are also provided.

*Boulder mass (axial dimensions $x$ rock density). Density was derived via the water displacement method. Based on samples of

Bembridge Limestone obtained from the study site a rock density of $2.4 \mathrm{~g} / \mathrm{cm}^{3}$ was recorded; all tagged boulders were formed of Bembridge Limestone.

Shape is defined by Zingg (1935), D - Disk, E - Equant, B - Bladed, P - Prolate 


\begin{tabular}{|c|c|c|c|c|c|c|c|c|c|c|c|c|c|c|c|c|}
\hline $\begin{array}{l}\text { RFID } \\
\text { No }\end{array}$ & $\begin{array}{c}\text { A } \\
\text { axis } \\
\text { (m) }\end{array}$ & $\begin{array}{c}\text { B } \\
\text { axis } \\
\text { (m) }\end{array}$ & $\begin{array}{c}\mathrm{C} \\
\text { axis } \\
(\mathrm{m})\end{array}$ & $\mathrm{MS}$ & Shape & $\begin{array}{l}\text { Mass } \\
(\mathrm{t}) \#\end{array}$ & $\begin{array}{l}\text { Times } \\
\text { trans }\end{array}$ & $\begin{array}{c}\text { S1 - S2 } \\
\text { (25 July } 15 \\
-3 \text { Feb 16) }\end{array}$ & $\begin{array}{c}\mathrm{S} 2-\mathrm{S} 3 \\
(3-17 \mathrm{Feb} \\
16)\end{array}$ & $\begin{array}{c}\text { S3 - S4 } \\
(17 \text { Feb - } 1 \\
\text { Apr 16) }\end{array}$ & $\begin{array}{c}\text { S4 - S5 } \\
\text { (1 Apr } 16- \\
23 \text { Sept } 16)\end{array}$ & $\begin{array}{c}\text { S5 - S6 } \\
\text { (23 Sept - } \\
25 \text { Nov 16) }\end{array}$ & $\begin{array}{c}\text { S6 - S7 } \\
\text { (25 Nov } 16 \\
-8 \text { Feb 17) }\end{array}$ & $\begin{array}{c}\text { S7 - S8 } \\
\text { (8 Feb - } 5 \\
\text { May 17) }\end{array}$ & $\begin{array}{c}\text { S8 - S9 } \\
\text { (5 May } 17 \text { - } \\
10 \text { May } 18)\end{array}$ & $\begin{array}{l}\text { Total IBTD } \\
(\mathrm{m})\end{array}$ \\
\hline 1102 & 1.10 & 0.70 & 0.40 & 4 & $B$ & 0.7 & 2 & 0.0 & 0.0 & $0.2\left(289^{\circ}\right)$ & 0.0 & $0.5\left(178^{\circ}\right)$ & 0.0 & 0.0 & 0.0 & 0.7 \\
\hline 1104 & 1.10 & 0.68 & 0.32 & 3 & $B$ & 0.6 & 1 & 0.0 & 0.0 & 0.0 & 0.0 & 0.0 & $1.5\left(336^{\circ}\right)$ & 0.0 & 0.0 & 1.5 \\
\hline 1105 & 1.57 & 0.87 & 0.25 & 3 & $B$ & 0.8 & 4 & 0.0 & $0.2\left(267^{\circ}\right)$ & $0.5\left(94^{\circ}\right)$ & $0.2\left(178^{\circ}\right)$ & 0.0 & 0.0 & 0.0 & $0.4\left(297^{\circ}\right)$ & 1.3 \\
\hline 1107 & 0.80 & 0.73 & 0.20 & 4 & $\mathrm{D}$ & 0.3 & 7 & $0.8\left(107^{\circ}\right)$ & 0.0 & $0.2\left(91^{\circ}\right)$ & $0.2\left(169^{\circ}\right)$ & $0.1\left(5^{\circ}\right)$ & $0.5\left(193^{\circ}\right)$ & $0.3\left(286^{\circ}\right)$ & $0.6\left(346^{\circ}\right)$ & 2.7 \\
\hline 1108 & 1.05 & 0.62 & 0.30 & 4 & $B$ & 0.5 & 3 & 0.0 & 0.0 & 0.0 & 0.0 & $0.2\left(86^{\circ}\right)$ & $0.5\left(282^{\circ}\right)$ & 0.0 & $9.0\left(154^{\circ}\right)$ & 9.7 \\
\hline 1109 & 0.98 & 0.69 & 0.25 & 4 & $\mathrm{D}$ & 0.4 & 2 & 0.0 & 0.0 & 0.0 & $1.6\left(71^{\circ}\right)$ & 0.0 & 0.0 & 0.0 & $1.6\left(256^{\circ}\right)$ & 3.2 \\
\hline 1111 & 1.05 & 0.60 & 0.25 & 4 & $B$ & 0.4 & 6 & $2.7\left(304^{\circ}\right)$ & $0.9\left(44^{\circ}\right)$ & $0.9\left(356^{\circ}\right)$ & $0.3\left(187^{\circ}\right)$ & 0.0 & $0.7\left(1^{\circ}\right)$ & 0.0 & $0.3\left(57^{\circ}\right)$ & 5.8 \\
\hline 1112 & 0.75 & 0.70 & 0.30 & 1 & $\mathrm{D}$ & 0.4 & 3 & $0.8\left(159^{\circ}\right)$ & 0.0 & 0.0 & $0.3\left(48^{\circ}\right)$ & 0.0 & $0.1\left(285^{\circ}\right)$ & 0.0 & 0.0 & 1.2 \\
\hline 1113 & 1.00 & 0.85 & 0.30 & 1 & D & 0.6 & 1 & $0.1\left(301^{\circ}\right)$ & 0.0 & 0.0 & 0.0 & 0.0 & 0.0 & 0.0 & 0.0 & 0.1 \\
\hline 1115 & 1.50 & 1.00 & 0.30 & 3 & $\mathrm{D}$ & 1.1 & 2 & $0.2\left(344^{\circ}\right)$ & 0.0 & $0.3\left(24^{\circ}\right)$ & 0.0 & 0.0 & 0.0 & 0.0 & 0.0 & 0.5 \\
\hline 1116 & 0.85 & 0.75 & 0.30 & 3 & B & 0.5 & 1 & 0.0 & 0.0 & 0.0 & 0.0 & 0.0 & 0.0 & 0.0 & $0.8\left(123^{\circ}\right)$ & 0.8 \\
\hline 1117 & 0.90 & 0.87 & 0.35 & 3 & D & 0.7 & 4 & $0.2\left(42^{\circ}\right)$ & $0.3\left(4^{\circ}\right)$ & $0.1\left(337^{\circ}\right)$ & 0.0 & 0.0 & 0.0 & 0.0 & $0.1\left(146^{\circ}\right)$ & 0.7 \\
\hline 1118 & 1.20 & 1.05 & 0.20 & 3 & $\mathrm{D}$ & 0.6 & 2 & $0.4\left(341^{\circ}\right)$ & 0.0 & 0.0 & 0.0 & 0.0 & 0.0 & 0.0 & $0.2\left(263^{\circ}\right)$ & 0.6 \\
\hline 1120 & 1.15 & 1.05 & 0.20 & 3 & $\mathrm{D}$ & 0.6 & 4 & $0.1\left(108^{\circ}\right)$ & 0.0 & 0.0 & 0.0 & $1.4\left(274^{\circ}\right)$ & $0.1\left(348^{\circ}\right)$ & $0.5\left(280^{\circ}\right)$ & 0.0 & 2.1 \\
\hline 1123 & 1.15 & 0.67 & 0.20 & $4 / 3$ & $B$ & 0.4 & 3 & $0.9\left(283^{\circ}\right)$ & 0.0 & 0.0 & 0.0 & 0.0 & $0.3\left(1^{\circ}\right)$ & $0.1\left(222^{\circ}\right)$ & 0.0 & 1.3 \\
\hline 1124 & 0.65 & 0.50 & 0.20 & 3 & $\mathrm{D}$ & 0.2 & 1 & $0.4\left(350^{\circ}\right)$ & 0.0 & 0.0 & 0.0 & 0.0 & 0.0 & 0.0 & 0.0 & 0.4 \\
\hline 1125 & 1.00 & 0.86 & 0.20 & 3 & D & 0.4 & 2 & 0.0 & 0.0 & 0.0 & 0.0 & 0.0 & 0.0 & $0.2\left(138^{\circ}\right)$ & $0.2\left(118^{\circ}\right)$ & 0.4 \\
\hline 1127 & 1.60 & 1.50 & 0.20 & $2 / 3$ & D & 1.2 & 5 & 0.0 & $7.2\left(280^{\circ}\right)$ & $1.2\left(327^{\circ}\right)$ & 0.0 & $0.6\left(340^{\circ}\right)$ & $1.1\left(294^{\circ}\right)$ & 0.0 & $0.1\left(315^{\circ}\right)$ & 10.2 \\
\hline 1128 & 0.80 & 0.50 & 0.25 & 4 & $B$ & 0.2 & 6 & $4.9\left(128^{\circ}\right)$ & $0.4\left(210^{\circ}\right)$ & $0.7\left(246^{\circ}\right)$ & $1.3\left(116^{\circ}\right)$ & $1.6\left(296^{\circ}\right)$ & 0.0 & 0.0 & $0.5\left(208^{\circ}\right)$ & 9.4 \\
\hline 1129 & 0.70 & 0.40 & 0.25 & 4 & $B$ & 0.2 & 4 & $0.7\left(22^{\circ}\right)$ & 0.0 & 0.0 & $0.8\left(182^{\circ}\right)$ & $0.1\left(334^{\circ}\right)$ & 0.0 & 0.0 & $1.1\left(349^{\circ}\right)$ & 2.7 \\
\hline 1130 & 1.05 & 0.60 & 0.25 & 4 & $B$ & 0.4 & 4 & 0.0 & $0.2\left(257^{\circ}\right)$ & 0.0 & $0.4\left(341^{\circ}\right)$ & $0.2\left(273^{\circ}\right)$ & 0.0 & 0.0 & $0.4\left(265^{\circ}\right)$ & 1.2 \\
\hline 1131 & 0.85 & 0.60 & 0.35 & 1 & D & 0.4 & 2 & $0.4\left(256^{\circ}\right)$ & 0.0 & 0.0 & $0.1\left(273^{\circ}\right)$ & 0.0 & 0.0 & 0.0 & 0.0 & 0.5 \\
\hline 1133 & 0.60 & 0.40 & 0.25 & 1 & $\mathrm{D}$ & 0.1 & 1 & $0.9\left(72^{\circ}\right)$ & 0.0 & 0.0 & 0.0 & 0.0 & 0.0 & 0.0 & 0.0 & 0.9 \\
\hline 1134 & 0.80 & 0.65 & 0.30 & 2 & $\mathrm{D}$ & 0.4 & 2 & 0.0 & 0.0 & 0.0 & 0.0 & 0.0 & $0.3\left(332^{\circ}\right)$ & 0.0 & $14.3\left(282^{\circ}\right)$ & 14.6 \\
\hline 1135 & 1.00 & 0.90 & 0.35 & 1 & $\mathrm{D}$ & 0.8 & 1 & $0.1\left(344^{\circ}\right)$ & 0.0 & 0.0 & 0.0 & 0.0 & 0.0 & 0.0 & 0.0 & 0.1 \\
\hline 1136 & 1.10 & 0.95 & 0.23 & 3 & $\mathrm{D}$ & 0.6 & 2 & 0.0 & $0.1\left(311^{\circ}\right)$ & 0.0 & 0.0 & 0.0 & 0.0 & 0.0 & $0.1\left(52^{\circ}\right)$ & 0.2 \\
\hline 1137 & 1.00 & 0.70 & 0.25 & 3 & D & 0.4 & 2 & 0.0 & 0.0 & $0.1\left(203^{\circ}\right)$ & $0.2\left(316^{\circ}\right)$ & 0.0 & 0.0 & 0.0 & 0.0 & 0.3 \\
\hline 1138 & 1.40 & 0.97 & 0.20 & 1 & D & 0.7 & 1 & 0.0 & 0.0 & 0.0 & 0.0 & 0.0 & 0.0 & $0.3\left(344^{\circ}\right)$ & 0.0 & 0.3 \\
\hline 1140 & 0.95 & 0.95 & 0.20 & $1 / 4$ & $\mathrm{D}$ & 0.4 & 7 & $0.5\left(311^{\circ}\right)$ & $0.8\left(343^{\circ}\right)$ & $0.2\left(169^{\circ}\right)$ & 0.0 & $0.2\left(174^{\circ}\right)$ & $8.9\left(265^{\circ}\right)$ & $2.3\left(334^{\circ}\right)$ & $0.3\left(7^{\circ}\right)$ & 13.2 \\
\hline 1141 & 1.15 & 0.45 & 0.30 & 1 & D & 0.4 & 1 & 0.0 & 0.0 & 0.0 & 0.0 & 0.0 & 0.0 & $0.1\left(106^{\circ}\right)$ & 0.0 & 0.1 \\
\hline 1142 & 1.30 & 0.90 & 0.45 & 1 & $\mathrm{D}$ & 1.3 & 2 & 0.0 & 0.0 & 0.0 & $0.1\left(263^{\circ}\right)$ & 0.0 & 0.0 & $0.1\left(240^{\circ}\right)$ & 0.0 & 0.2 \\
\hline 1143 & 0.85 & 0.65 & 0.20 & 4 & $\mathrm{D}$ & 0.3 & 2 & $16.1\left(317^{\circ}\right)$ & 0.0 & 0.0 & 0.0 & 0.0 & $5.4\left(335^{\circ}\right)$ & 0.0 & 0.0 & 21.5 \\
\hline 1144 & 0.95 & 0.80 & 0.20 & 4 & $\mathrm{D}$ & 0.4 & 3 & 0.0 & 0.0 & 0.0 & 0.0 & $4.6\left(313^{\circ}\right)$ & $6.3\left(282^{\circ}\right)$ & 0.0 & $5.5\left(356^{\circ}\right)$ & 16.4 \\
\hline 1145 & 1.20 & 0.67 & 0.20 & 3 & $B$ & 0.4 & 1 & 0.0 & $0.4\left(13^{\circ}\right)$ & 0.0 & 0.0 & 0.0 & 0.0 & 0.0 & 0.0 & 0.4 \\
\hline 1146 & 1.05 & 1.00 & 0.20 & 3 & $\mathrm{D}$ & 0.5 & 3 & 0.0 & $0.1\left(350^{\circ}\right)$ & 0.0 & 0.0 & 0.0 & 0.0 & $0.1\left(335^{\circ}\right)$ & $0.3\left(335^{\circ}\right)$ & 0.5 \\
\hline 1147 & 0.70 & 0.60 & 0.45 & 3 & $E$ & 0.5 & 3 & $0.3\left(288^{\circ}\right)$ & 0.0 & $0.3\left(102^{\circ}\right)$ & 0.0 & 0.0 & $0.3\left(281^{\circ}\right)$ & 0.0 & 0.0 & 0.9 \\
\hline 1148 & 0.85 & 0.75 & 0.48 & $2 / 3$ & $\mathrm{D}$ & 0.7 & 5 & $15.0\left(315^{\circ}\right)$ & $0.1\left(346^{\circ}\right)$ & $1.2\left(39^{\circ}\right)$ & 0.0 & $0.1\left(217^{\circ}\right)$ & $0.1\left(279^{\circ}\right)$ & 0.0 & 0.0 & 16.5 \\
\hline 1150 & 0.70 & 0.70 & 0.17 & $\begin{array}{lll}4 & \\
\end{array}$ & $\mathrm{D}$ & 0.2 & 3 & $1.7\left(359^{\circ}\right)$ & 0.0 & $0.4\left(21^{\circ}\right)$ & 0.0 & $2.1\left(343^{\circ}\right)$ & 0.0 & 0.0 & 0.0 & 4.2 \\
\hline 1151 & 1.10 & 0.65 & 0.27 & 4 & $\mathrm{~B}$ & 0.5 & 4 & $2.0\left(273^{\circ}\right)$ & $1.4\left(246^{\circ}\right)$ & 0.0 & 0.0 & $1.0\left(200^{\circ}\right)$ & $1.1\left(234^{\circ}\right)$ & 0.0 & 0.0 & 5.5 \\
\hline \multicolumn{8}{|c|}{ CUMMULATIVE TRANSPORT - EVENTS $(n)$ / DISTANCE (m) } & $21 / 49.2$ & $12 / 12.1$ & $13 / 6.3$ & $11 / 5.5$ & $13 / 12.7$ & $15 / 27.2$ & $9 / 4.0$ & $18 / 35.8$ & $112 / 152.8$ \\
\hline
\end{tabular}

This article is protected by copyright. All rights reserved. 
Table III: Black Rock - summary of individual boulder characteristics, distance $(\mathrm{m})$ and direction $\left(^{\circ}\right)$ of transported boulders between specified survey periods. Cumulative survey transport totals are also provided.

\begin{tabular}{|c|c|c|c|c|c|c|c|c|c|c|c|c|c|c|c|c|c|}
\hline $\begin{array}{l}\text { RFID } \\
\text { No }\end{array}$ & $\begin{array}{c}\text { A } \\
\text { axis } \\
\text { (m) }\end{array}$ & $\begin{array}{l}\text { B } \\
\text { axis } \\
\text { (m) }\end{array}$ & $\begin{array}{c}\text { C } \\
\text { axis } \\
\text { (m) }\end{array}$ & MS & Shape & $\begin{array}{l}\text { Mass } \\
(\mathrm{t})^{\#}\end{array}$ & $\begin{array}{l}\text { Times } \\
\text { trans }\end{array}$ & $\begin{array}{c}\text { S1 - S2 } \\
\text { (10 July } 15- \\
3 \text { Dec } 15 \text { ) }\end{array}$ & $\begin{array}{c}\text { S2 - S3 } \\
\text { (3 Dec'15 - } \\
6 \text { Jan 16) }\end{array}$ & $\begin{array}{c}\text { S3 - S4 } \\
\text { (6 Jan } 16- \\
19 \text { Feb 16) }\end{array}$ & $\begin{array}{c}\text { S4 - S5 } \\
\text { (19 Feb } 16- \\
31 \text { May } 16)\end{array}$ & $\begin{array}{c}\text { S5 - S6 } \\
\text { (31 May } 16- \\
1 \text { Sept 16) }\end{array}$ & $\begin{array}{c}\text { S6 - S7 } \\
\text { (1 Sept } 16- \\
9 \text { Dec 16) }\end{array}$ & $\begin{array}{c}\text { S7 - S8 } \\
\text { (9 Dec } 16- \\
22 \text { Feb 17) }\end{array}$ & $\begin{array}{c}\text { S8 - S9 } \\
\text { (22 Feb } 17 \text { - } \\
24 \text { May } 17 \text { ) }\end{array}$ & $\begin{array}{c}\text { S9 - S10 } \\
\text { (24 May } 17 \text { - } \\
11 \text { July } 18 \text { ) }\end{array}$ & $\begin{array}{l}\text { Total IBTD } \\
(\mathrm{m})\end{array}$ \\
\hline 1152 & 1.50 & 1.00 & 0.50 & 3 & $\mathrm{D}$ & 1.8 & 3 & $0.1\left(229^{\circ}\right)$ & $0.1\left(25^{\circ}\right)$ & 0.0 & 0.0 & 0.0 & 0.0 & 0.0 & 0.0 & $0.1\left(224^{\circ}\right)$ & 0.3 \\
\hline 1154 & 0.90 & 0.80 & 0.70 & 3 & $\mathrm{E}$ & 1.2 & 1 & 0.0 & 0.0 & 0.0 & $0.1\left(262^{\circ}\right)$ & 0.0 & 0.0 & 0.0 & 0.0 & 0.0 & 0.1 \\
\hline 1158 & 1.35 & 0.80 & 0.35 & 3 & $\mathrm{~B}$ & 0.9 & 1 & 0.0 & 0.0 & 0.0 & 0.0 & 0.0 & 0.0 & 0.0 & 0.0 & $0.3\left(103^{\circ}\right)$ & 0.3 \\
\hline 1160 & 1.30 & 1.00 & 0.25 & 3 & $\mathrm{D}$ & 0.8 & 4 & $0.2\left(239^{\circ}\right)$ & $0.1\left(346^{\circ}\right)$ & 0.0 & $0.1\left(161^{\circ}\right)$ & 0.0 & 0.0 & $0.2\left(64^{\circ}\right)$ & 0.0 & 0.0 & 0.6 \\
\hline 1162 & 1.25 & 1.10 & 0.25 & 3 & $\mathrm{D}$ & 0.8 & 1 & 0.0 & 0.0 & 0.0 & 0.0 & 0.0 & 0.0 & $0.1\left(264^{\circ}\right)$ & 0.0 & 0.0 & 0.1 \\
\hline 1163 & 0.75 & 0.70 & 0.20 & $4 / 3$ & D & 0.3 & 5 & $2.9\left(147^{\circ}\right)$ & $2.8\left(337^{\circ}\right)$ & $4.0\left(343^{\circ}\right)$ & $0.1\left(327^{\circ}\right)$ & 0.0 & $0.2\left(145^{\circ}\right)$ & 0.0 & 0.0 & 0.0 & 10.0 \\
\hline 1164 & 0.75 & 0.50 & 0.35 & 3 & $\mathrm{E}$ & 0.3 & 5 & $1.5\left(244^{\circ}\right)$ & $0.7\left(54^{\circ}\right)$ & $0.2\left(43^{\circ}\right)$ & 0.0 & 0.0 & 0.0 & $0.2\left(359^{\circ}\right)$ & 0.0 & $1.3\left(12^{\circ}\right)$ & 3.9 \\
\hline 1165 & 1.00 & 0.75 & 0.35 & 3 & $\mathrm{D}$ & 0.6 & 1 & 0.0 & 0.0 & 0.0 & 0.0 & 0.0 & 0.0 & 0.0 & 0.0 & $0.4\left(199^{\circ}\right)$ & 0.4 \\
\hline 1166 & 1.35 & 1.15 & 0.40 & 4 & D & 1.5 & 2 & 0.0 & $0.1\left(243^{\circ}\right)$ & 0.0 & 0.0 & 0.0 & 0.0 & $0.1\left(86^{\circ}\right)$ & 0.0 & 0.0 & 0.2 \\
\hline 1168 & 0.65 & 0.60 & 0.40 & 4 & $\mathrm{E}$ & 0.4 & 6 & $0.4\left(46^{\circ}\right)$ & $0.6\left(318^{\circ}\right)$ & $1.4\left(351^{\circ}\right)$ & $2.1\left(23^{\circ}\right)$ & 0.0 & $0.9\left(179^{\circ}\right)$ & 0.0 & 0.0 & $1.0\left(28^{\circ}\right)$ & 6.4 \\
\hline 1175 & 0.80 & 0.52 & 0.25 & 3 & B & 0.2 & 4 & $0.2\left(294^{\circ}\right)$ & 0.0 & 0.0 & 0.0 & $0.1\left(280^{\circ}\right)$ & 0.0 & 0.0 & $0.8\left(14^{\circ}\right)$ & $0.2\left(305^{\circ}\right)$ & 1.3 \\
\hline 1177 & 0.45 & 0.40 & 0.40 & 1 & $\mathrm{E}$ & 0.2 & 1 & $0.2\left(179^{\circ}\right)$ & 0.0 & 0.0 & 0.0 & 0.0 & 0.0 & 0.0 & 0.0 & 0.0 & 0.2 \\
\hline 1178 & 0.60 & 0.50 & 0.40 & 3 & $\mathrm{E}$ & 0.3 & 2 & $0.1\left(229^{\circ}\right)$ & 0.0 & $0.1\left(58^{\circ}\right)$ & 0.0 & 0.0 & 0.0 & 0.0 & 0.0 & 0.0 & 0.2 \\
\hline 1179 & 0.50 & 0.50 & 0.25 & 3 & $\mathrm{D}$ & 0.2 & 2 & $0.5\left(164^{\circ}\right)$ & $0.2\left(78^{\circ}\right)$ & 0.0 & 0.0 & 0.0 & 0.0 & 0.0 & 0.0 & 0.0 & 0.7 \\
\hline 1180 & 1.25 & 0.80 & 0.30 & 3 & B & 0.7 & 1 & 0.0 & 0.0 & 0.0 & 0.0 & $0.1\left(22^{\circ}\right)$ & 0.0 & 0.0 & 0.0 & 0.0 & 0.1 \\
\hline 1181 & 0.80 & 0.50 & 0.30 & $4 / 3$ & B & 0.3 & 2 & $1.2\left(141^{\circ}\right)$ & $0.2\left(200^{\circ}\right)$ & 0.0 & 0.0 & 0.0 & 0.0 & 0.0 & 0.0 & 0.0 & 1.4 \\
\hline 1182 & 0.70 & 0.60 & 0.40 & 4 & $\mathrm{E}$ & 0.4 & 2 & $0.2\left(93^{\circ}\right)$ & $0.1\left(87^{\circ}\right)$ & 0.0 & 0.0 & 0.0 & 0.0 & 0.0 & 0.0 & 0.0 & 0.3 \\
\hline 1183 & 0.60 & 0.50 & 0.40 & 4 & $\mathrm{E}$ & 0.3 & 5 & $0.8\left(232^{\circ}\right)$ & $0.1\left(352^{\circ}\right)$ & $0.1\left(73^{\circ}\right)$ & $0.2\left(313^{\circ}\right)$ & $0.3\left(61^{\circ}\right)$ & 0.0 & 0.0 & 0.0 & 0.0 & 1.5 \\
\hline 1184 & 0.85 & 0.45 & 0.35 & 3 & $\mathrm{P}$ & 0.3 & 1 & 0.0 & 0.0 & 0.0 & 0.0 & 0.0 & 0.0 & 0.0 & 0.0 & $0.5\left(331^{\circ}\right)$ & 0.5 \\
\hline 1185 & 0.65 & 0.60 & 0.40 & 4 & $\mathrm{E}$ & 0.4 & 7 & 0.0 & 0.0 & $0.6\left(317^{\circ}\right)$ & $2.5\left(16^{\circ}\right)$ & $0.8\left(23^{\circ}\right)$ & $2.1\left(69^{\circ}\right)$ & $0.4\left(32^{\circ}\right)$ & $0.3\left(37^{\circ}\right)$ & $4.8\left(31^{\circ}\right)$ & 11.5 \\
\hline 1186 & 0.65 & 0.45 & 0.40 & 3 & $E$ & 0.3 & 1 & $0.1\left(26^{\circ}\right)$ & 0.0 & 0.0 & 0.0 & 0.0 & 0.0 & 0.0 & 0.0 & 0.0 & 0.1 \\
\hline 1187 & 2.90 & 1.60 & 0.45 & $4 / 3$ & B & 5.0 & 3 & 0.0 & 0.0 & $0.9\left(4^{\circ}\right)$ & $6.4\left(335^{\circ}\right)$ & 0.0 & $2.5\left(110^{\circ}\right)$ & 0.0 & 0.0 & 0.0 & 9.8 \\
\hline 1188 & 2.90 & 2.85 & 0.60 & 4 & $\mathrm{D}$ & 11.9 & 2 & 0.0 & 0.0 & 0.0 & $0.5\left(60^{\circ}\right)$ & 0.0 & $3.1\left(308^{\circ}\right)$ & 0.0 & 0.0 & 0.0 & 3.6 \\
\hline 1189 & 2.00 & 1.70 & 0.30 & 4 & D & 2.4 & 3 & 0.0 & 0.0 & $0.2\left(110^{\circ}\right)$ & $1.6\left(351^{\circ}\right)$ & 0.0 & $0.8\left(354^{\circ}\right)$ & 0.0 & 0.0 & 0.0 & 2.6 \\
\hline 1190 & 1.40 & 0.60 & 0.40 & 2 & $\mathrm{P}$ & 0.8 & 1 & 0.0 & 0.0 & $0.1\left(290^{\circ}\right)$ & 0.0 & 0.0 & 0.0 & 0.0 & 0.0 & 0.0 & 0.1 \\
\hline 1192 & 1.25 & 0.75 & 0.35 & $4 / 3$ & B & 0.8 & 4 & 0.0 & $1.1\left(15^{\circ}\right)$ & $1.8\left(334^{\circ}\right)$ & $5.4\left(354^{\circ}\right)$ & 0.0 & 0.0 & $0.1\left(87^{\circ}\right)$ & 0.0 & 0.0 & 8.4 \\
\hline 1195 & 0.85 & 0.45 & 0.40 & 4 & $\mathrm{P}$ & 0.4 & 1 & 0.0 & 0.0 & 0.0 & $0.9\left(324^{\circ}\right)$ & 0.0 & 0.0 & 0.0 & 0.0 & 0.0 & 0.9 \\
\hline 1197 & 0.95 & 0.55 & 0.50 & 4 & $\mathrm{P}$ & 0.6 & 4 & $0.2\left(283^{\circ}\right)$ & $0.8\left(253^{\circ}\right)$ & $0.9\left(82^{\circ}\right)$ & $7.8\left(348^{\circ}\right)$ & 0.0 & 0.0 & 0.0 & 0.0 & 0.0 & 9.7 \\
\hline 1199 & 0.80 & 0.50 & 0.40 & 1 & $\mathrm{P}$ & 0.4 & 2 & 0.0 & 0.0 & $0.2\left(216^{\circ}\right)$ & 0.0 & 0.0 & 0.0 & 0.0 & 0.0 & $0.2\left(228^{\circ}\right)$ & 0.4 \\
\hline 7352 & 0.50 & 0.27 & 0.20 & 4 & $\mathrm{P}$ & 0.1 & 2 & $0.7\left(295^{\circ}\right)$ & 0.0 & 0.0 & 0.0 & 0.0 & 0.0 & 0.0 & 0.0 & $0.4\left(228^{\circ}\right)$ & 1.1 \\
\hline 7353 & 1.20 & 0.85 & 0.30 & 3 & D & 0.7 & 1 & 0.0 & 0.0 & 0.0 & 0.0 & 0.0 & 0.0 & 0.0 & 0.0 & $2.7\left(20^{\circ}\right)$ & 2.7 \\
\hline 7354 & 0.58 & 0.40 & 0.25 & 4 & D & 0.1 & 1 & 0.0 & 0.0 & 0.0 & 0.0 & 0.0 & 0.0 & 0.0 & 0.0 & $0.6\left(135^{\circ}\right)$ & 0.6 \\
\hline 7356 & 0.45 & 0.35 & 0.30 & 4 & $\mathrm{E}$ & 0.1 & 2 & 0.0 & 0.0 & 0.0 & 0.0 & 0.0 & 0.0 & $0.1\left(109^{\circ}\right)$ & 0.0 & $0.1\left(262^{\circ}\right)$ & 0.2 \\
\hline \multicolumn{8}{|c|}{ CUMMULATIVE TRANSPORT - EVENTS $(n)$ / DISTANCE $(m)$} & $15 / 9.3$ & $12 / 6.9$ & $12 / 10.5$ & $12 / 27.7$ & $4 / 1.3$ & $6 / 9.6$ & $7 / 1.2$ & $2 / 1.1$ & $13 / 12.6$ & $83 / 80.2$ \\
\hline
\end{tabular}

This article is protected by copyright. All rights reserved. 
Table IV. Summary of boulder transport values by morphological setting at Bembridge Ledge and Black Rock.

\begin{tabular}{|c|c|c|c|c|c|}
\hline & $\begin{array}{l}\text { Morphological } \\
\text { setting (MS) }\end{array}$ & $\begin{array}{c}\text { Transport total } \\
\text { (m) } \\
\text { (\% of total) }\end{array}$ & $\begin{array}{l}\text { No. of times } \\
\text { transported } \\
\text { (\% of total) }\end{array}$ & $\begin{array}{c}\text { No. of boulders } \\
\text { (movers/non-movers) }\end{array}$ & $\begin{array}{c}\text { Mean transport } \\
\text { distance per } \\
\text { event }(\mathrm{m})\end{array}$ \\
\hline \multirow{5}{*}{ 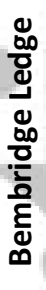 } & 1 & $14.0(9 \%)$ & 17 (15\%) & $13(9 / 4)$ & 0.8 \\
\hline & 2 & $36.8(24 \%)$ & $4(3 \%)$ & $4(3 / 1)$ & 9.2 \\
\hline & 3 & $15.5(10 \%)$ & $42(38 \%)$ & $20(14 / 6)$ & 0.4 \\
\hline & 4 & 86.5 (57\%) & 49 (44\%) & $13(13 / 0)$ & 1.8 \\
\hline & TOTAL & 152.8 & 112 & $50(39 / 11)$ & 1.4 \\
\hline & \multicolumn{5}{|l|}{+1} \\
\hline \multirow{5}{*}{ 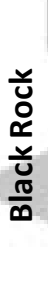 } & 1 & $0.6(1 \%)$ & $3(4 \%)$ & $3(2 / 1)$ & 0.2 \\
\hline & 2 & $0.1(0 \%)$ & $1(1 \%)$ & $2(1 / 1)$ & 0.1 \\
\hline & 3 & $14.3(18 \%)$ & 32 (38\%) & $25(14 / 11)$ & 0.4 \\
\hline & 4 & $65.2(81 \%)$ & 47 (57\%) & $24(8 / 16)$ & 1.4 \\
\hline & TOTAL & 80.2 & 83 & $54(25 / 29)$ & 1.0 \\
\hline \multirow{5}{*}{ 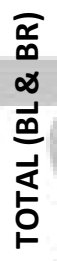 } & 1 & $14.6(6 \%)$ & $20(10 \%)$ & $16(11 / 5)$ & 0.7 \\
\hline & 2 & $36.9(16 \%)$ & $5(3 \%)$ & $6(4 / 2)$ & 7.4 \\
\hline & 3 & $29.8(13 \%)$ & 74 (38\%) & $45(28 / 17)$ & 0.4 \\
\hline & 4 & $151.7(65 \%)$ & 96 (49\%) & $37(21 / 16)$ & 1.6 \\
\hline & TOTAL & 233.0 & 195 & $104(64 / 40)$ & 1.2 \\
\hline
\end{tabular}


Table V. Mann-Whitney test results; boulder transport distances summarised by morphological setting (MS1 / MS2 / MS3 - constrained; MS4 - unconstrained).

\begin{tabular}{|c|c|c|}
\hline Bembridge Ledge $(n=50)$ & $p$-value & $\begin{array}{l}\text { Median transport distance }(\mathrm{m}) \\
\text { Constrained / Unconstrained }\end{array}$ \\
\hline Constrained ( $n=37)$ vs. Unconstrained $(n=13)$ & 0.0001 & 0.4 / 4.2 \\
\hline $\begin{array}{c}\text { Constrained ( } n=26) \text { vs. Unconstrained }(n=13) \\
\text { (exc. non-movers) }\end{array}$ & 0.0010 & $0.6 / 4.2$ \\
\hline
\end{tabular}

\begin{tabular}{|c|c|c|}
\hline Black Rock $(\boldsymbol{n}=\mathbf{5 4})$ & $\boldsymbol{p}$-value & $\begin{array}{c}\text { Median transport distance }(\mathbf{m}) \\
\text { Constrained } / \text { Unconstrained }\end{array}$ \\
\hline Constrained $(n=30)$ vs. Unconstrained $(n=24)$ & 0.0323 & $0.1 / 0.8$ \\
\hline \begin{tabular}{c} 
Constrained $\left(\begin{array}{c}n=17) \text { vs. Unconstrained }(n=16) \\
\text { (exc. non-movers) }\end{array}\right.$ \\
\hline
\end{tabular} & 0.0017 & $0.3 / 2.0$ \\
\hline
\end{tabular}

\begin{tabular}{|c|c|c|}
\hline Bembridge Ledge \& Black Rock $(\boldsymbol{n}=104)$ & $p$-value & $\begin{array}{c}\text { Median transport distance }(\mathbf{m}) \\
\text { Constrained } / \text { Unconstrained }\end{array}$ \\
\hline Constrained $(n=67)$ vs. Unconstrained $(n=37)$ & 0.0002 & $0.2 / 1.5$ \\
\hline $\begin{array}{c}\text { Constrained }(n=43) \text { vs. Unconstrained }(n=29) \\
\text { (exc. non-movers) }\end{array}$ & 0.0000 & $0.5 / 3.2$ \\
\hline
\end{tabular}

This article is protected by copyright. All rights reserved. 
Table VI. Summary of transport at BL and associated maximum inshore wave conditions recorded at Sandown Pier.

\begin{tabular}{|c|c|c|c|c|c|c|c|c|c|c|}
\hline & $\begin{array}{c}\text { Duration } \\
\text { between } \\
\text { surveys } \\
\text { (days) }\end{array}$ & $\begin{array}{c}\text { Daily } \\
\text { transport } \\
\text { distance } \\
\text { (m) }\end{array}$ & $\begin{array}{l}\text { Total mass of } \\
\text { transported } \\
\text { boulders }(\mathrm{t})\end{array}$ & $\begin{array}{l}\text { No. of } \\
\text { transport } \\
\text { events }\end{array}$ & $\begin{array}{l}\text { Transport } \\
\text { distance } \\
\text { (m) }\end{array}$ & $\begin{array}{l}\text { Mean } \\
\text { IBTD } \\
(\mathrm{m})\end{array}$ & $\begin{array}{l}\text { Max. } H_{s} \\
(\mathrm{~m})\end{array}$ & $\begin{array}{c}\text { Max. } \\
H_{\max }(m)\end{array}$ & $\begin{array}{c}\text { Wave } \\
\text { direction } \\
\left(^{\circ}\right)\end{array}$ & $\begin{array}{l}\text { Wave } \\
\text { period } \\
\text { (s) }\end{array}$ \\
\hline $\begin{array}{c}\text { S4 - S5: } \\
23 \text { Sept - } 25 \text { Nov '16 }\end{array}$ & 63 & 0.2 & 6.3 & 13 & 12.7 & 1.0 & 2.3 & 2.9 & 154 & 8.0 \\
\hline $\begin{array}{c}\text { S5 - S6: } \\
25 \text { Nov'16 - } 8 \text { Feb '17 }\end{array}$ & 75 & 0.4 & 7.6 & 15 & 27.2 & 1.8 & 1.6 & 2.3 & 115 & 8.0 \\
\hline
\end{tabular}




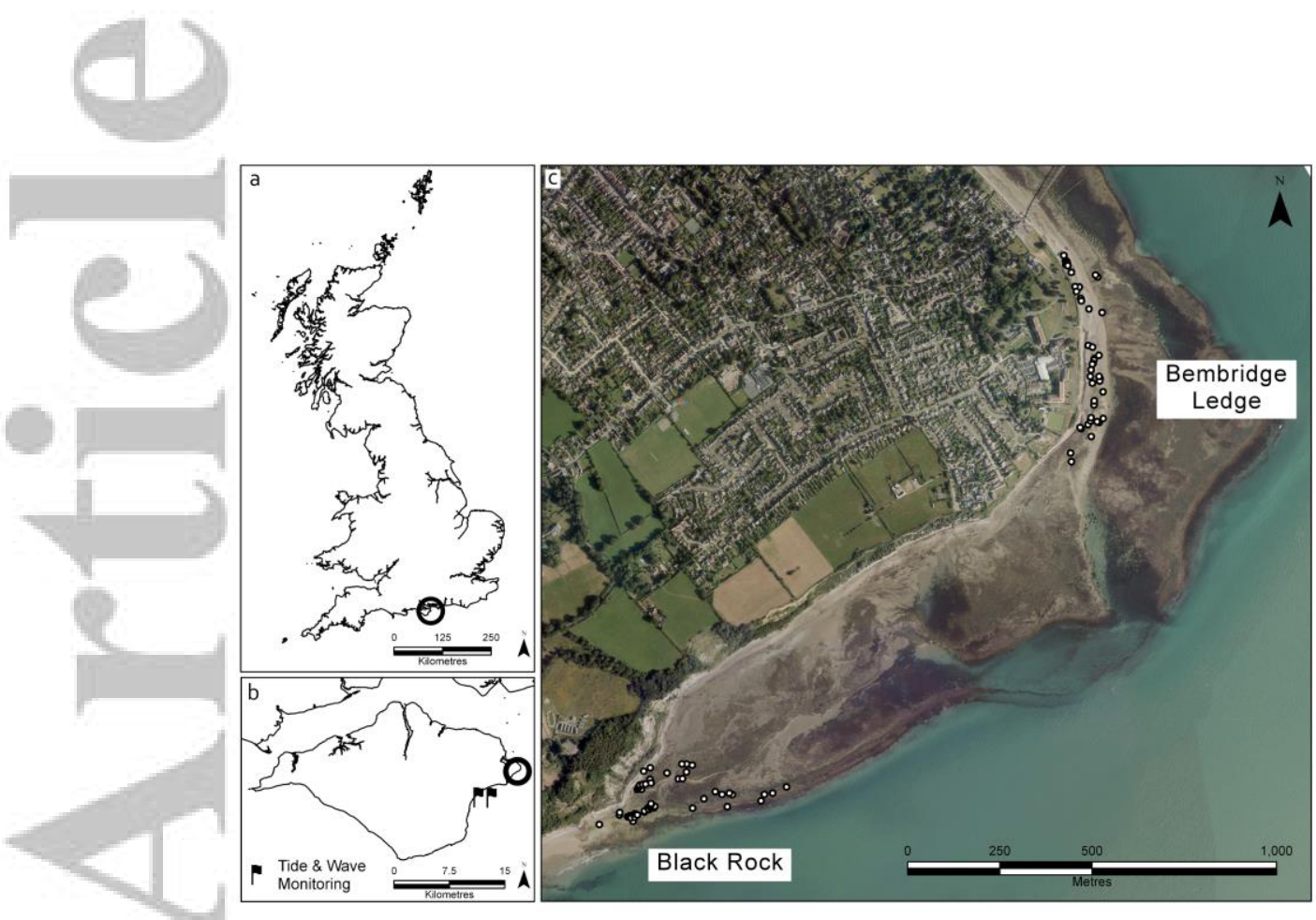

Figure 1. Location of study sites (a) Isle of Wight, (U.K.); (b) Bembridge, on the easterly point of the Isle of Wight, wave and tidal monitoring stations relative to site location; (c) study sites, Bembridge Ledge (sheltered) and Black Rock (moderately exposed), tagged boulders are indicated by the circular symbols. 


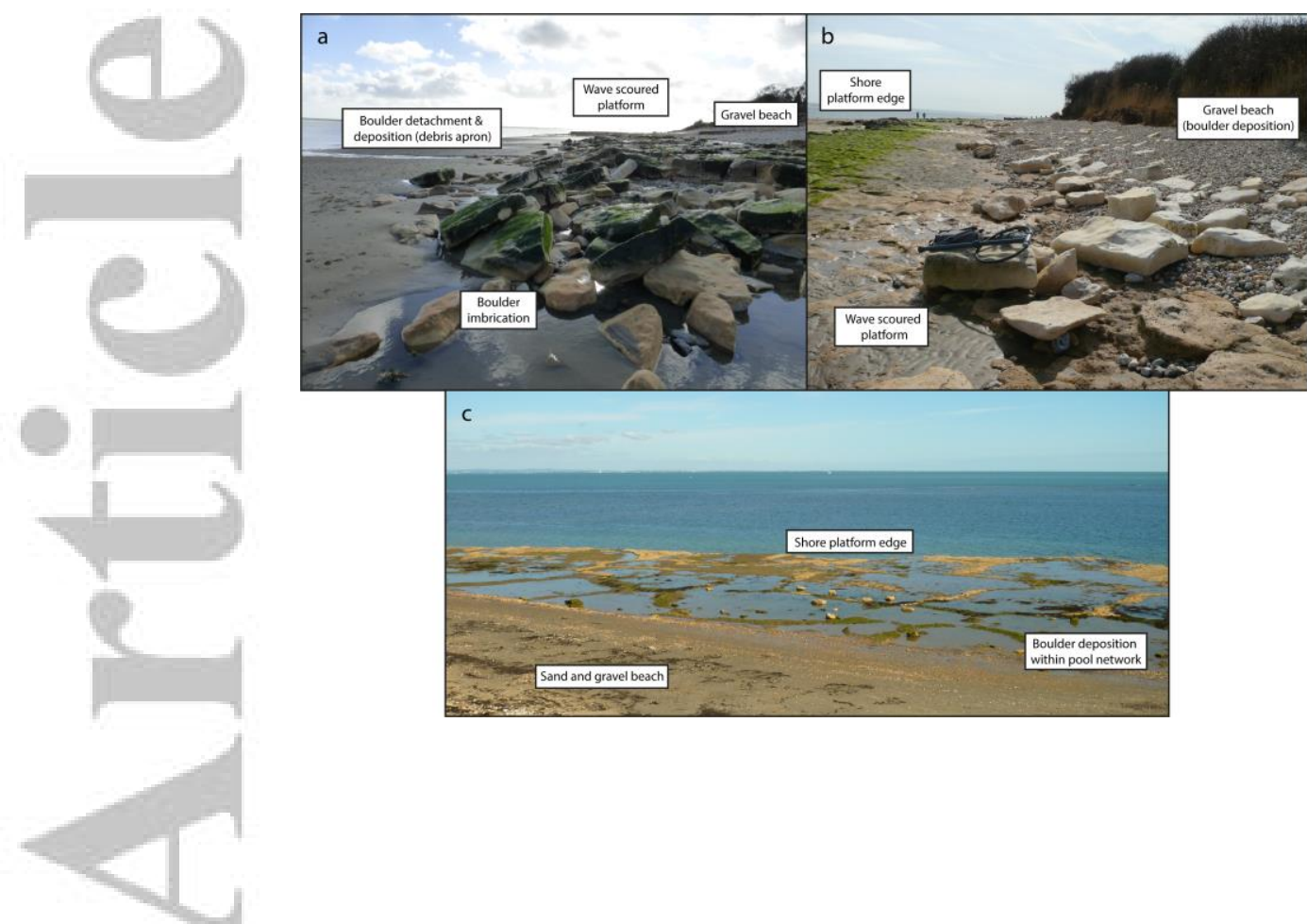

Figure 2. Bembridge Ledge (a) boulder production at the platform edge; (b) shore platform and boulder deposition on the gravel beach; (c) deposition of detached boulders in shallow, intertidal pools. 


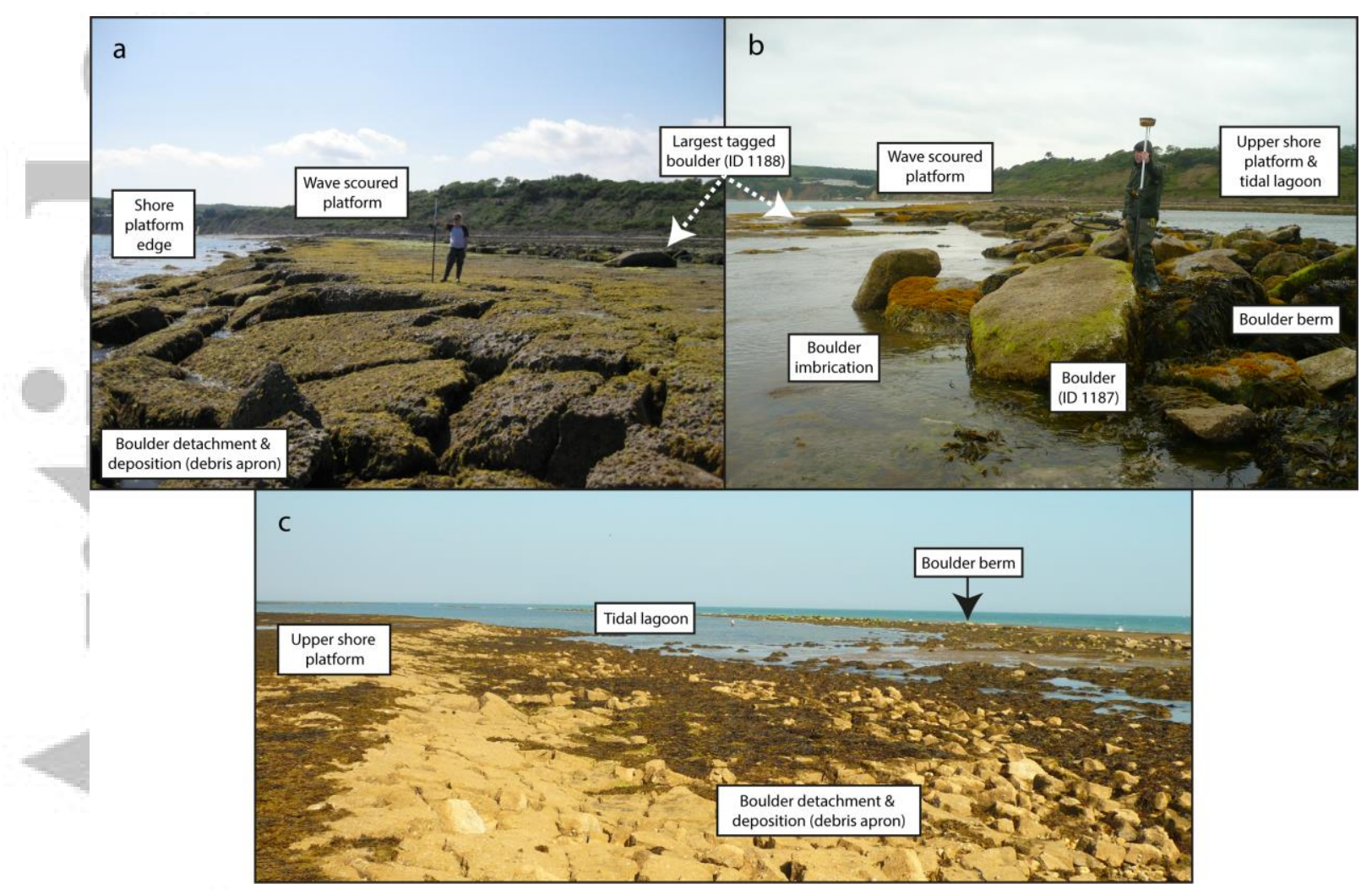

Figure 3. Black Rock (a) boulder production, transport and deposition; (b) boulder deposition creates an extensive boulder berm, the measured clast (ID: 1187) has an estimated mass of $5 \mathrm{t}$. The largest tagged boulder is identified in figures $\mathrm{a}$ and $\mathrm{b}$ (tag ID: 1188; (c) boulder deposition at the front of the upper platform. The arrow indicating the boulder berm identifies the approximate location of image capture in Figures $3 a$ and 3b. For scale, the DGNSS pole is extended to a height of $2.0 \mathrm{~m}$. 


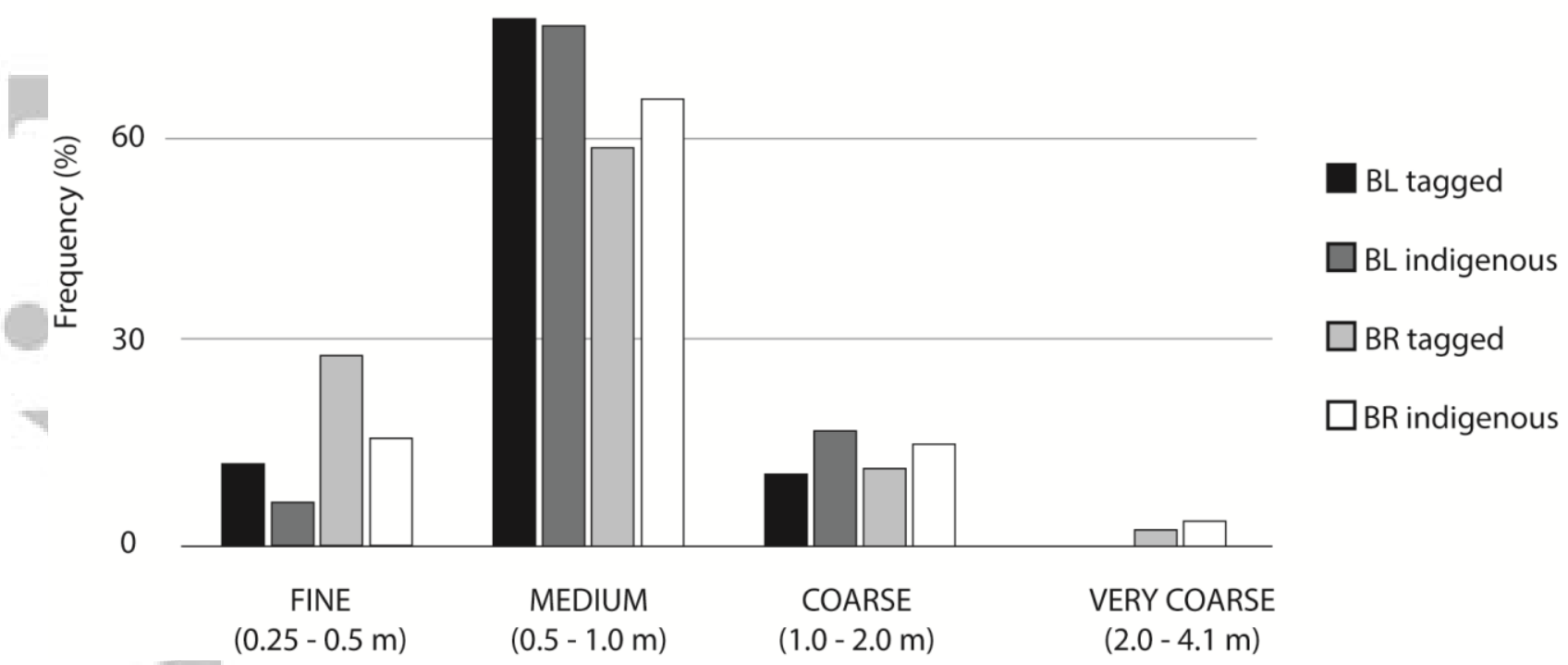

Figure 4. Frequency (\%) of boulder size classification of indigenous and tagged boulders at $\mathrm{BL}$ and $\mathrm{BR}$ based on intermediate $(I$ ) axial dimensions (classified in accordance with Blair and McPherson, 1999). 

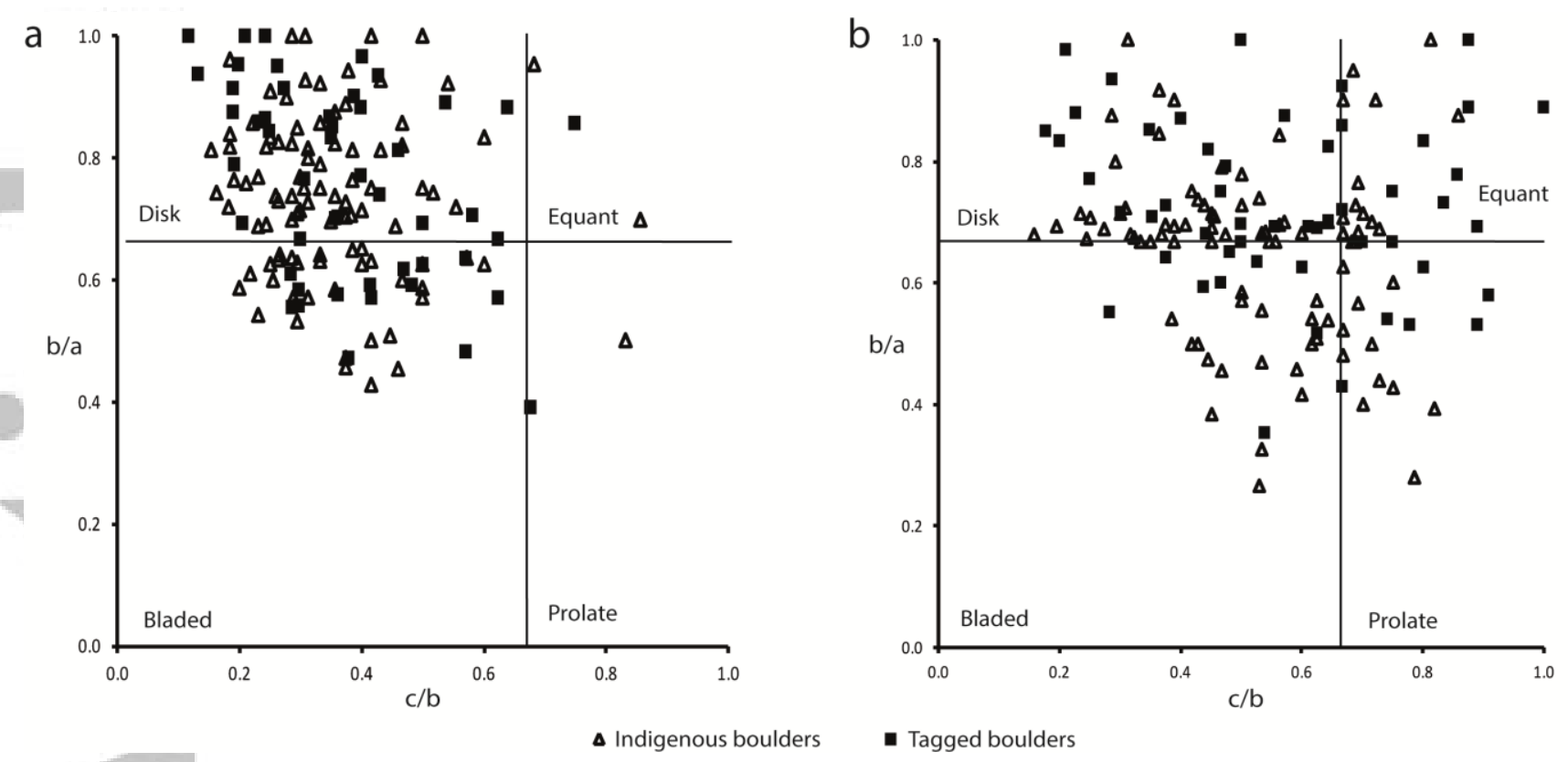

Figure 5. Zingg plots defining clast shape of indigenous and tagged boulder populations at (a) BL and (b) BR. 


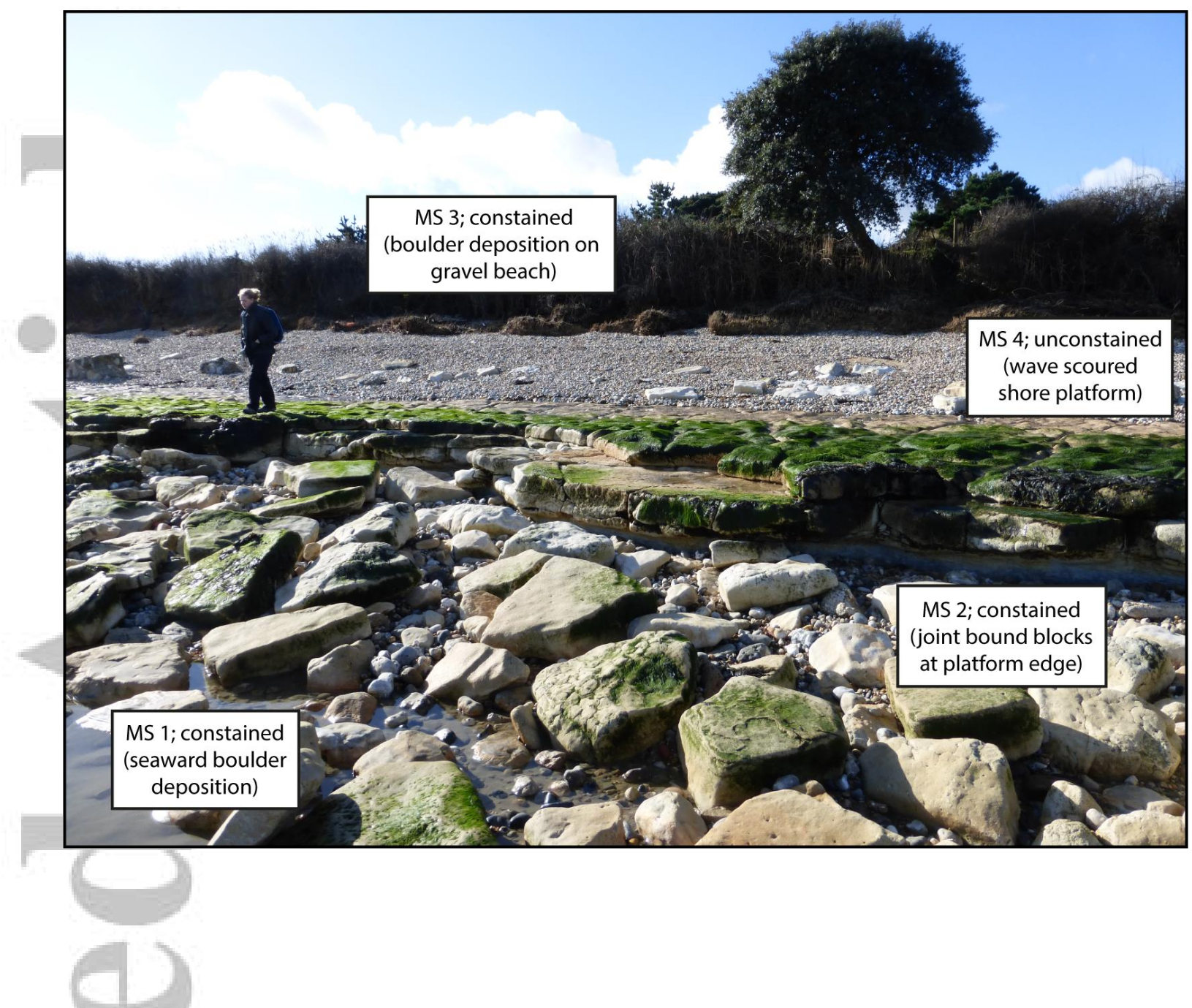

Figure 6. Examples of the four morphological settings (MS) as identified at BL.

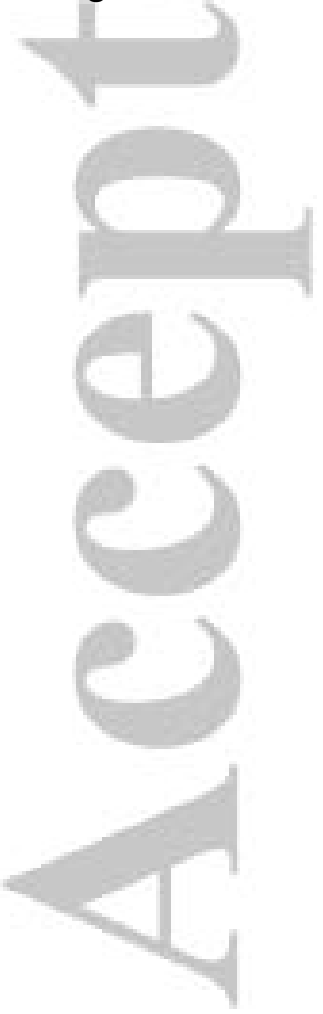

This article is protected by copyright. All rights reserved. 


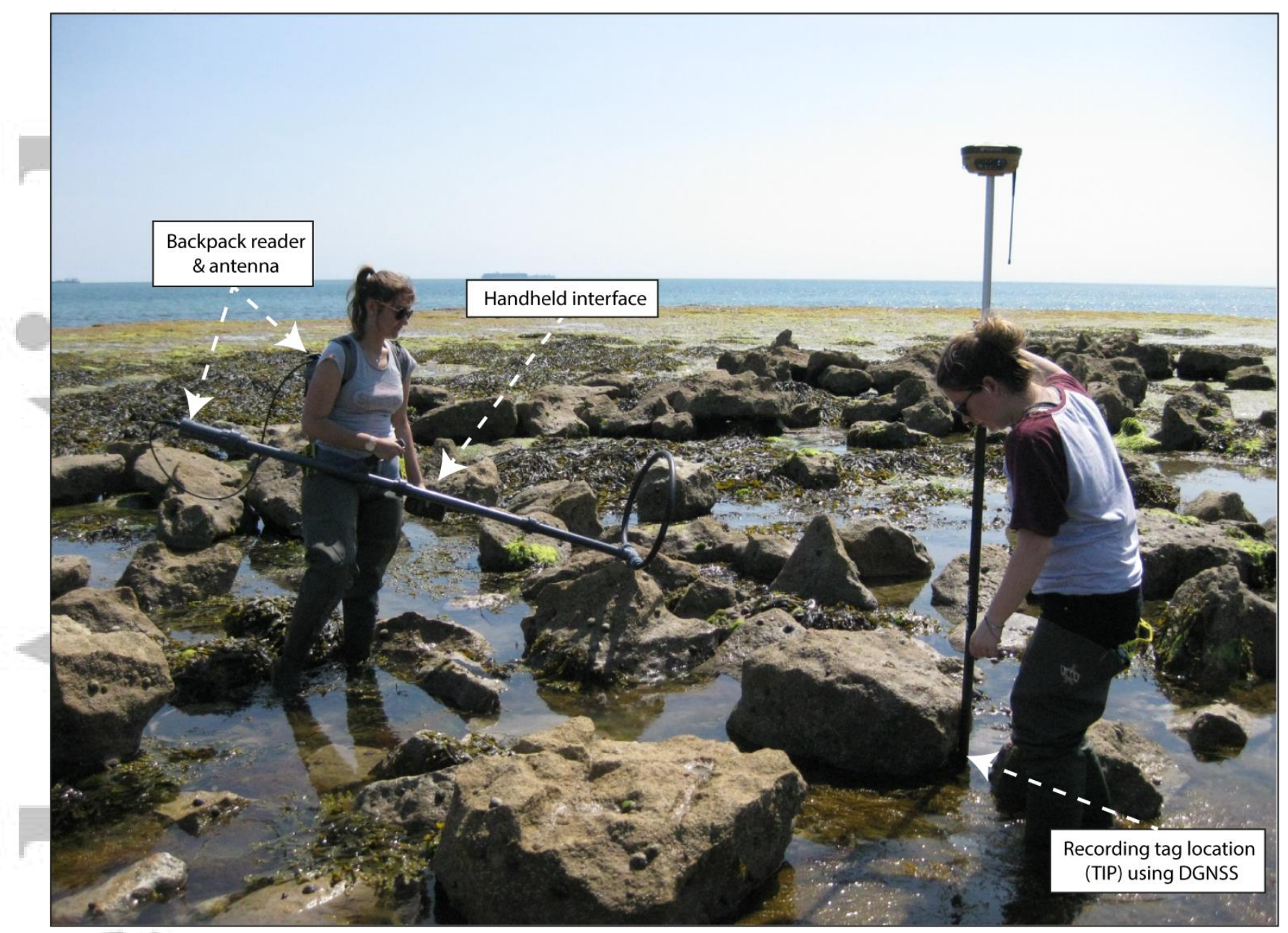

Figure 7. RFID tagged boulder relocation at BR using tag detection equipment (at left) and recording of boulder location using DGNSS (at right). For scale, the DGNSS pole is extended to a height of $2.0 \mathrm{~m}$.

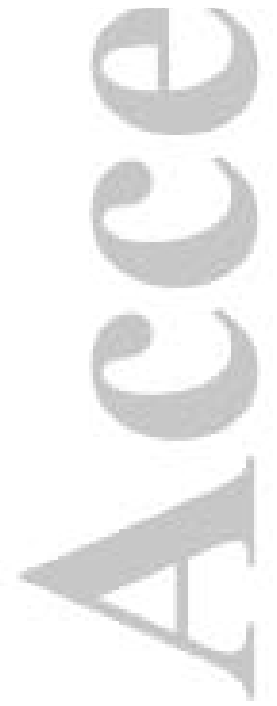

This article is protected by copyright. All rights reserved. 


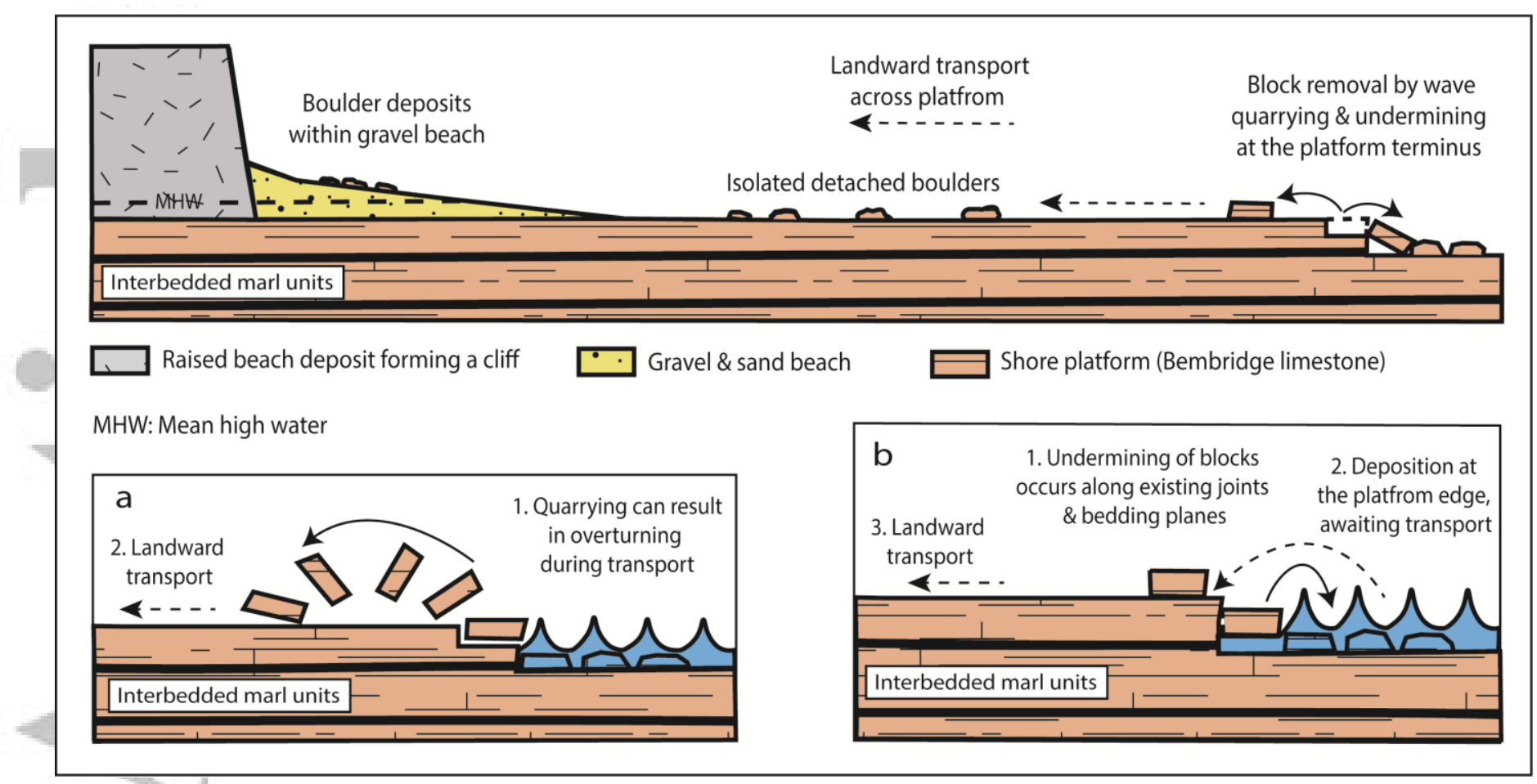

Figure 8. Bembridge Ledge - schematic diagram identifying modes of boulder production and transport; inset (a) the removal of blocks by quarrying; inset (b) block removal by undermining. 


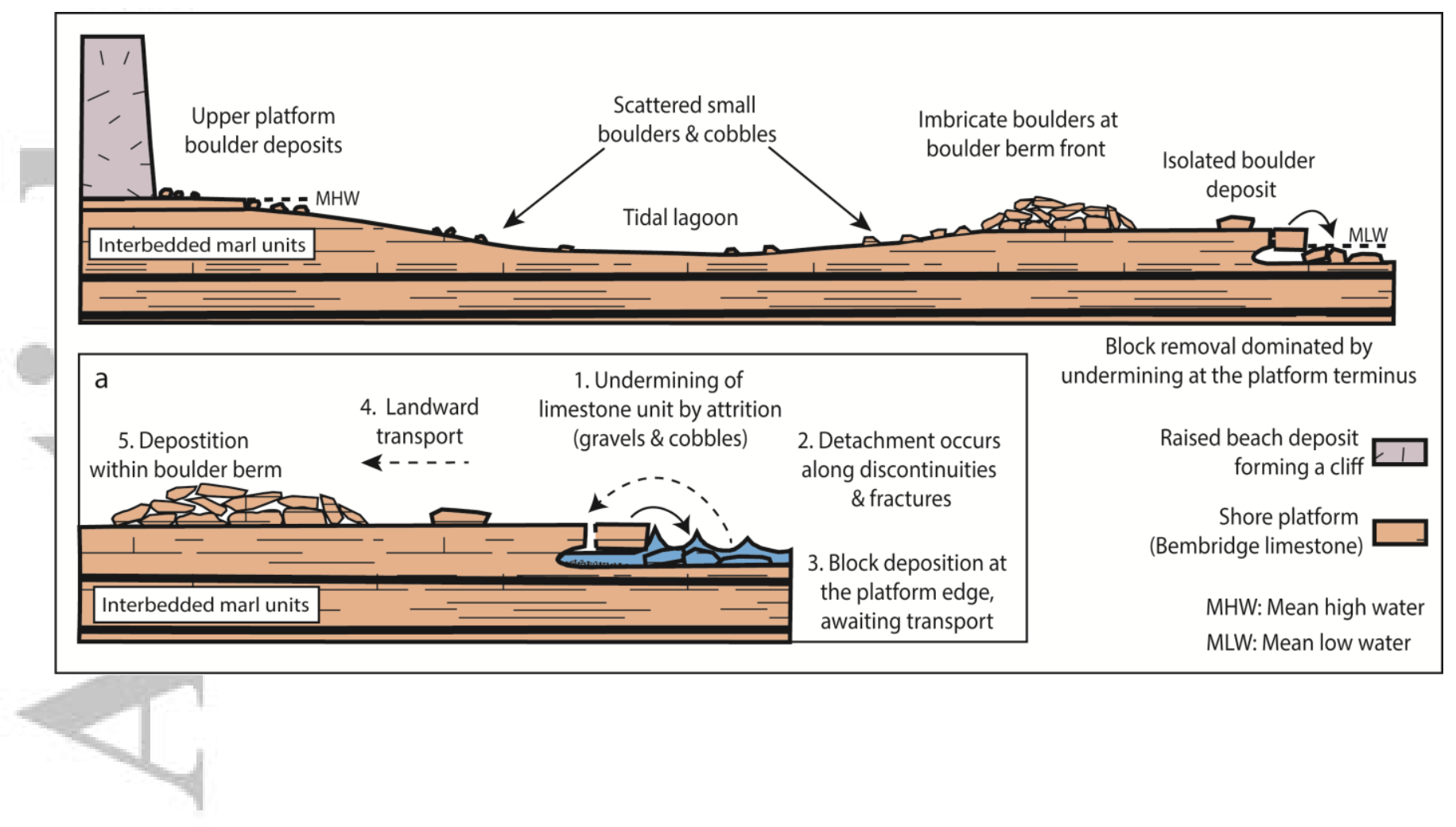

Figure 9. Black Rock - schematic diagram identifying modes of boulder production and transport; inset (a) the removal of blocks by undermining at the shore platform terminus. 

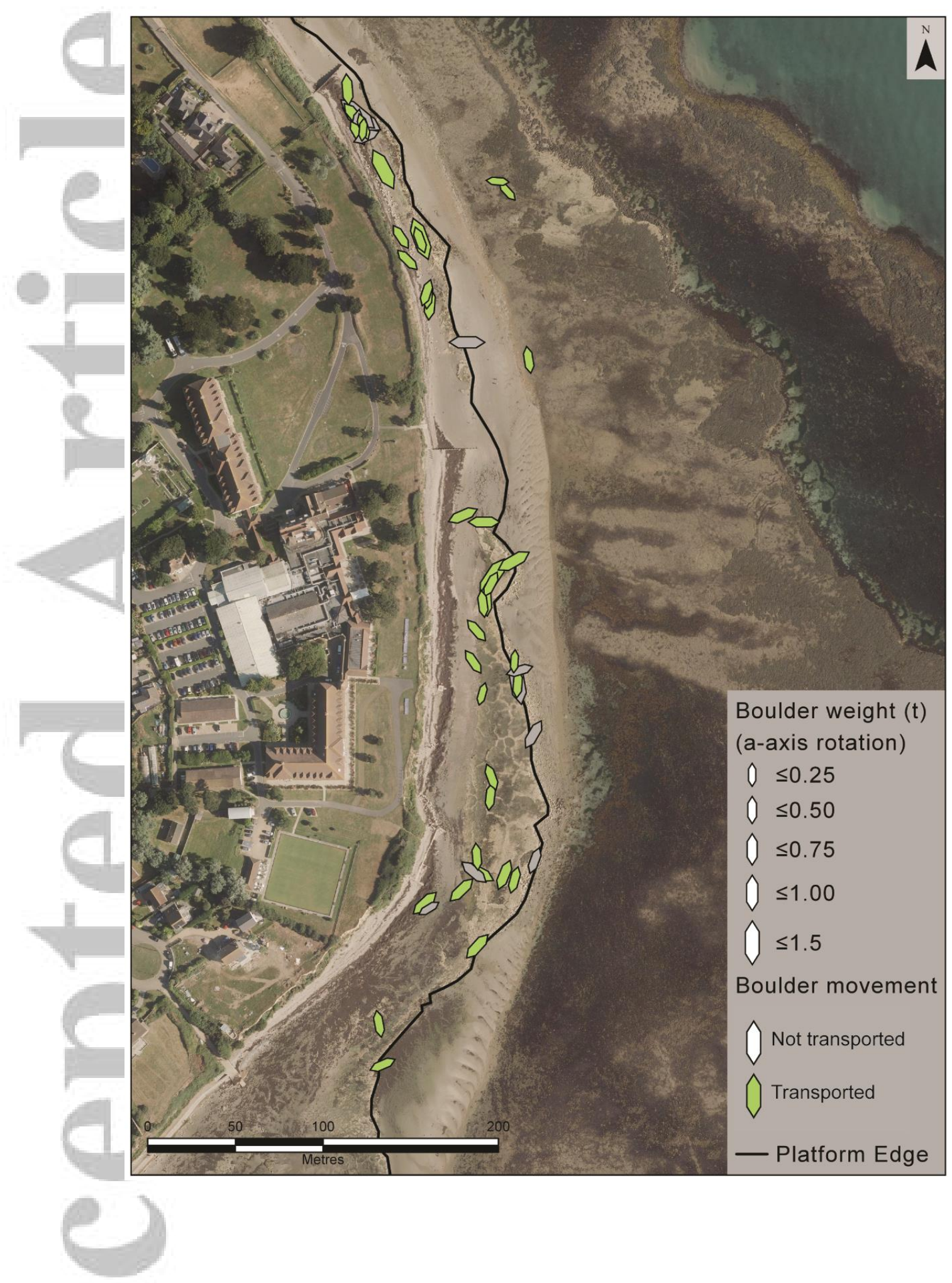

Figure 10. Bembridge Ledge site map identifying tagged boulder location, mass range, a-axis orientation and transport capacity.

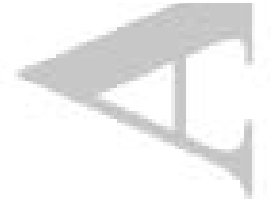

This article is protected by copyright. All rights reserved. 


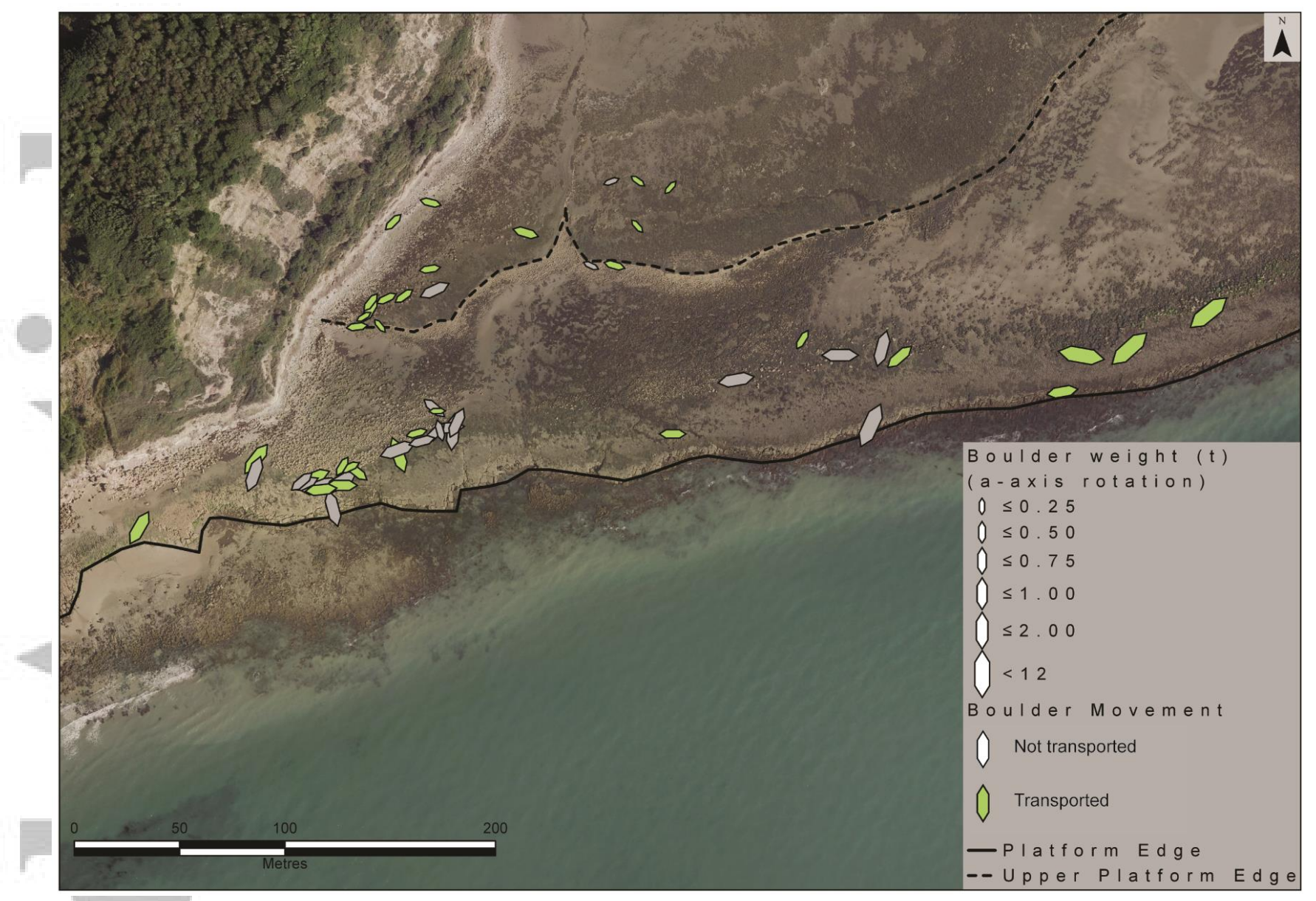

Figure 11. Black Rock site map identifying tagged boulder location, mass range, aaxis orientation and transport capacity. 

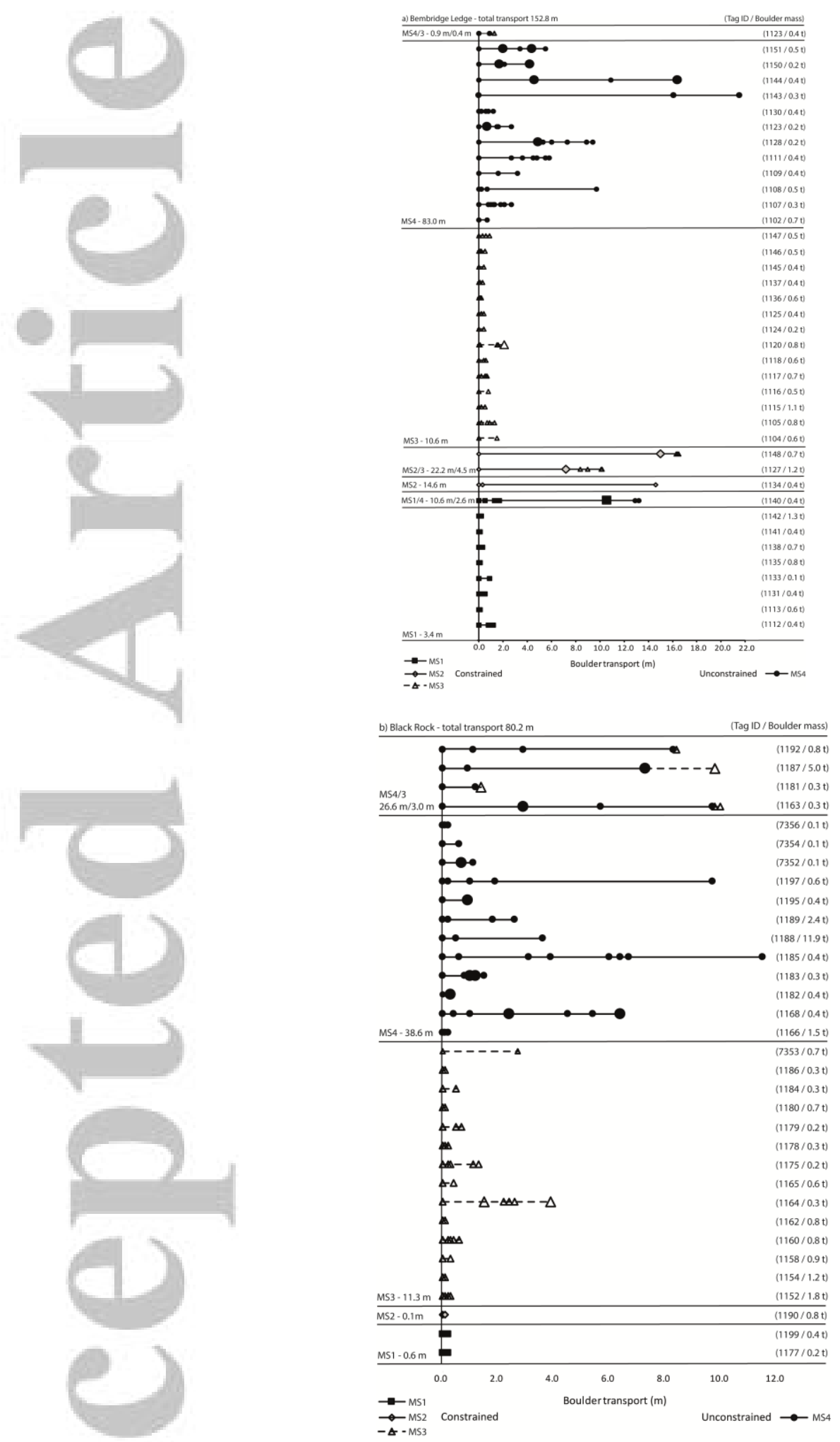

Figure 12. Individual boulder transport events identified by MS at (a) Bembridge Ledge and (b) Black Rock. 


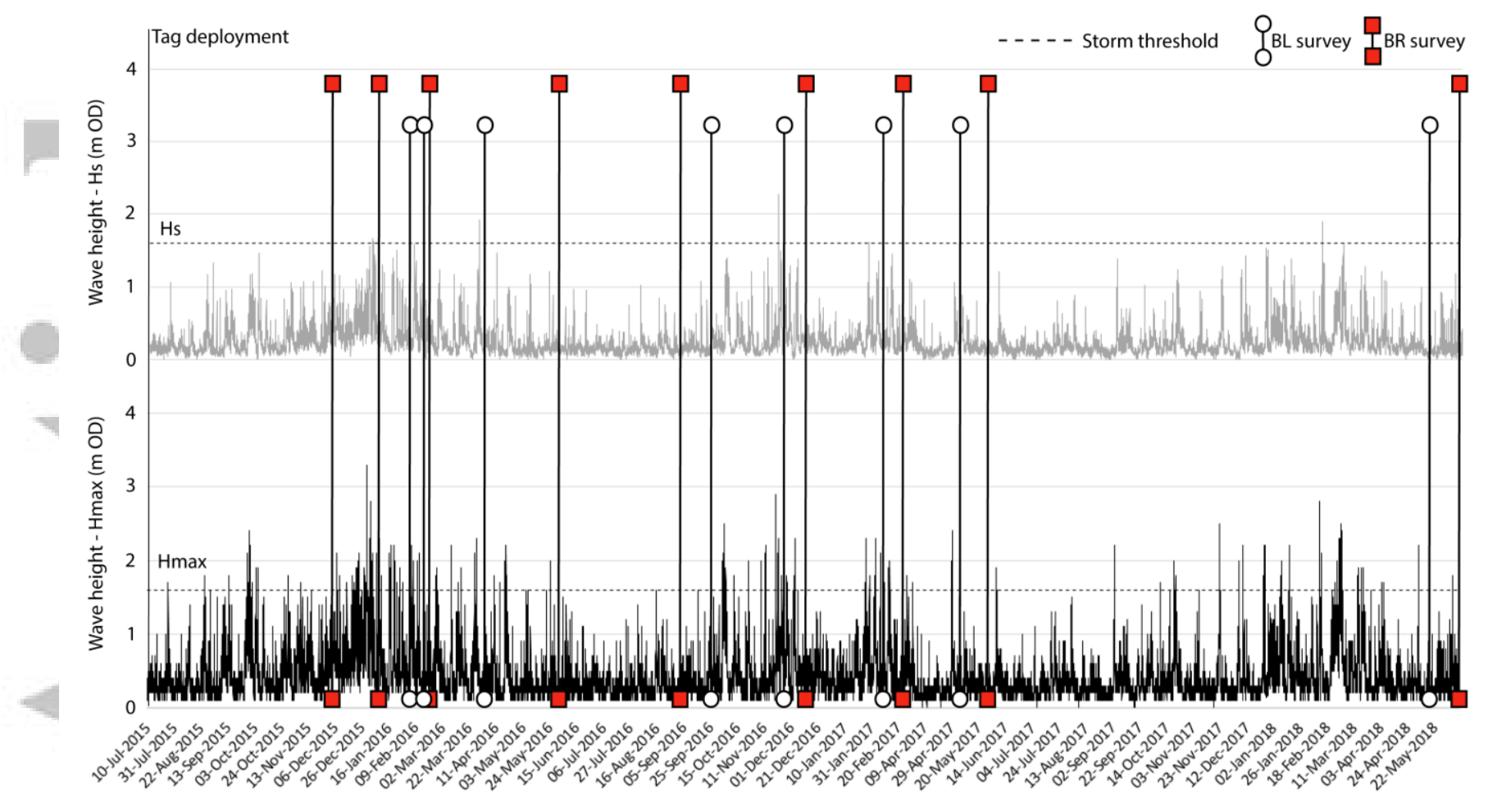

Figure 13. Inshore wave data from Sandown Pier $\left(H_{s}\right.$ and $\left.H_{\max }\right)$ and CCO storm threshold value $(1.6 \mathrm{~m})$. Boulder relocation surveys are identified as indicated relative to wave activity.

This article is protected by copyright. All rights reserved. 

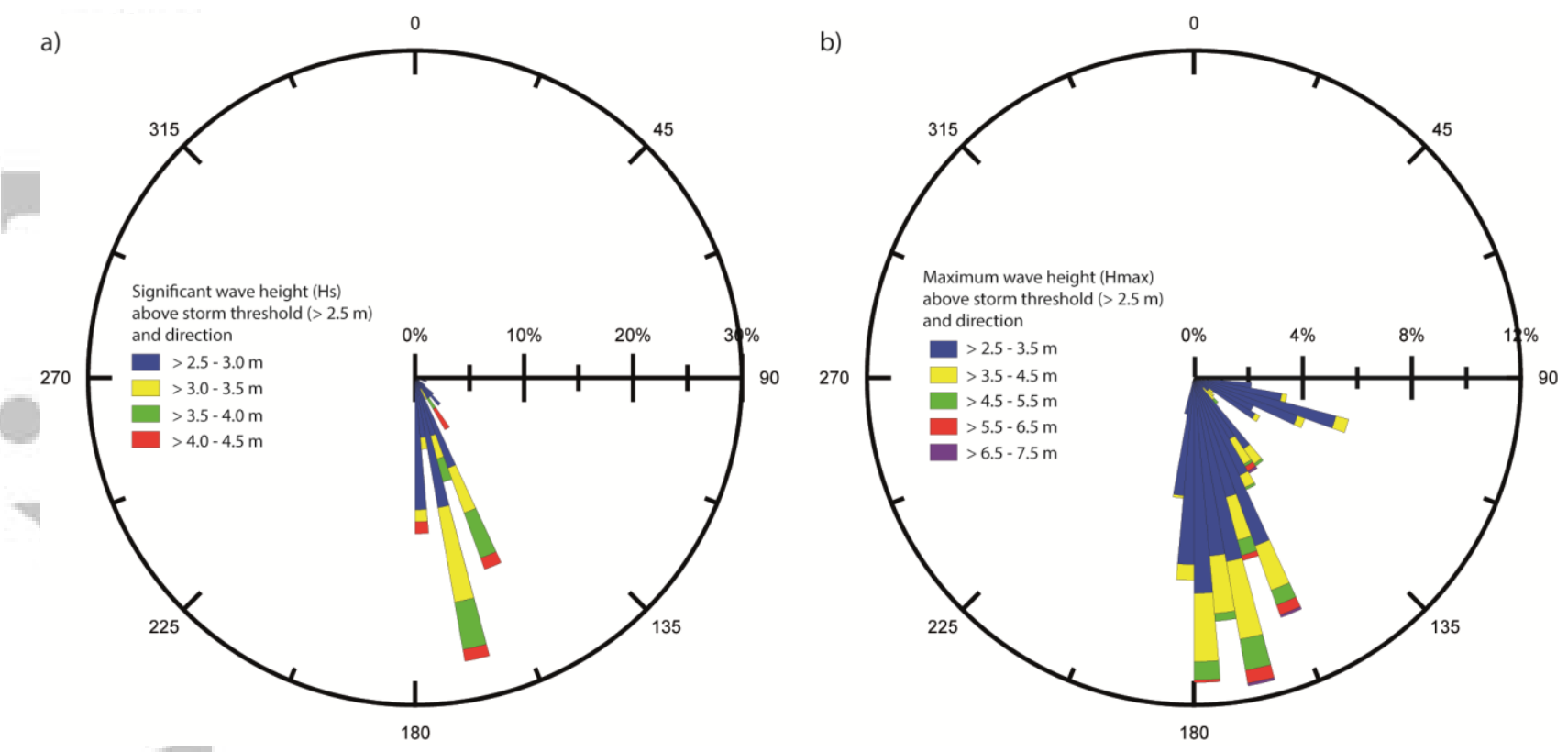

Figure 14. Nearshore wave height (Sandown Bay), frequency (\%) and direction $\left({ }^{\circ}\right) .(\mathrm{a})$ significant wave height: $H_{s}(m)$; (b) maximum wave height: $H_{\max }(m)$. 


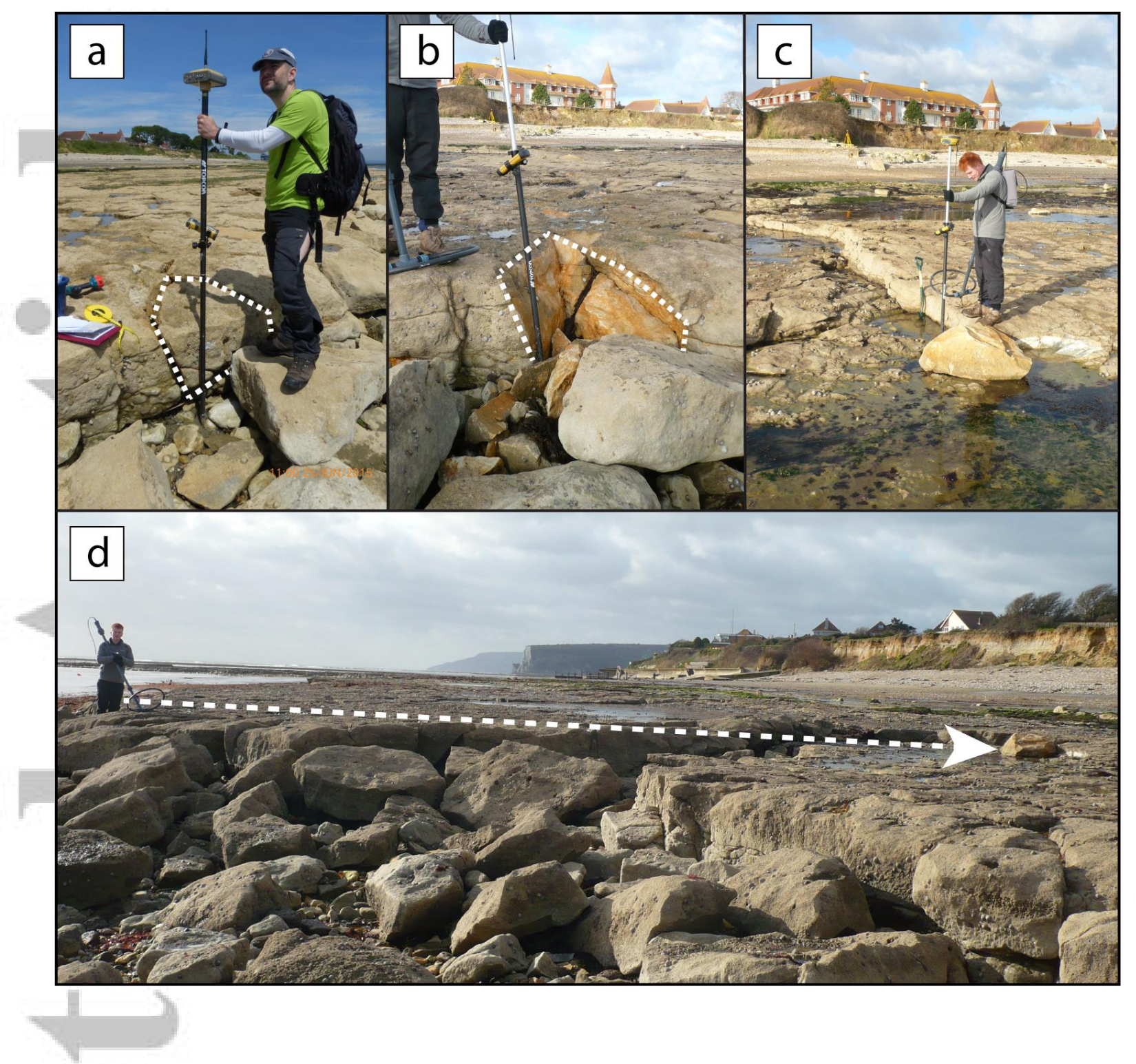

Figure 15. Bembridge Ledge - block removal by quarrying from the platform edge, tag ID: 1148. (a) pre-transport tagged boulder; (b) post-transport boulder socket; (c) posttransport deposition; (d) transport pathway, as indicated by the arrow, pre-transport detachment setting (at left) to deposition (at right). Note the active rotational sliding of raised beach cliff (at right). For scale, the DGNSS pole is extended to a height of 2.0 $\mathrm{m}$. 

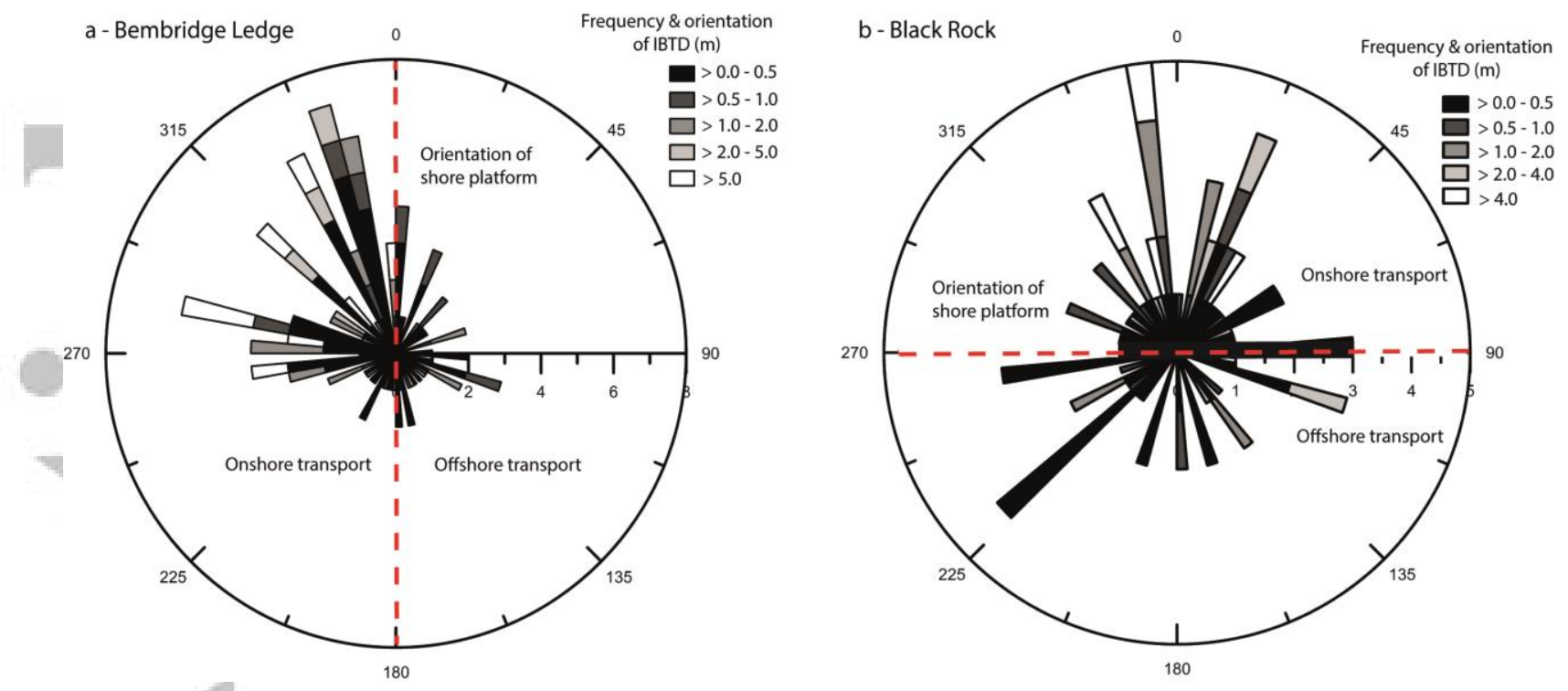

Figure 16. Frequency and orientation of boulder transport categorised by IBTD (m) as specified in the figure legends. Shore platform orientation is indicated by the centrally located dashed line. (a) Bembridge Ledge; (b) Black Rock. 

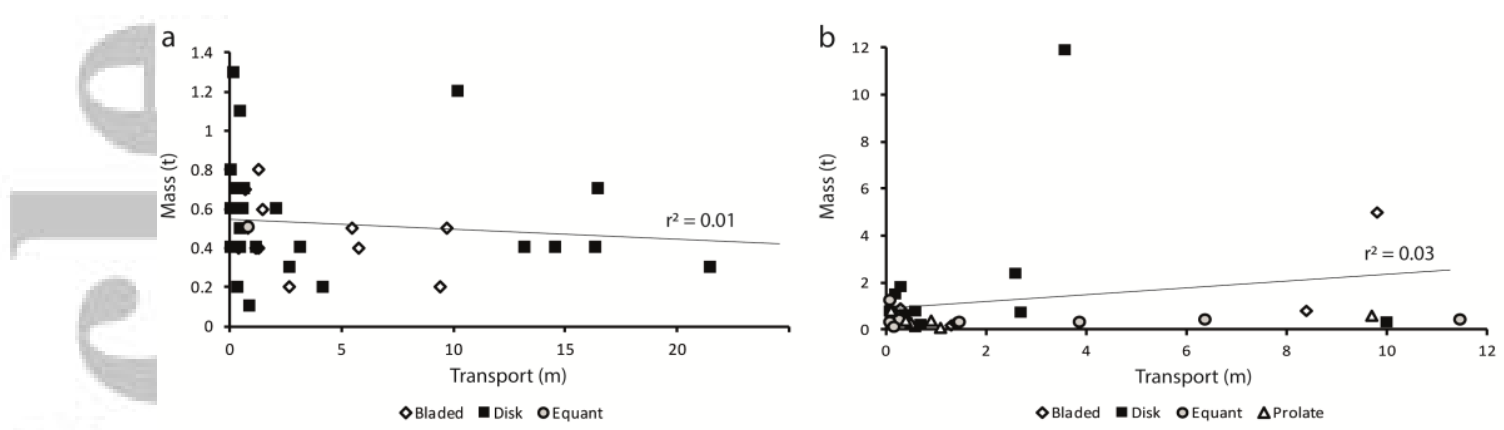

Figure 17. Recorded transport distance against boulder mass (a) Bembridge Ledge; (b) Black Rock.

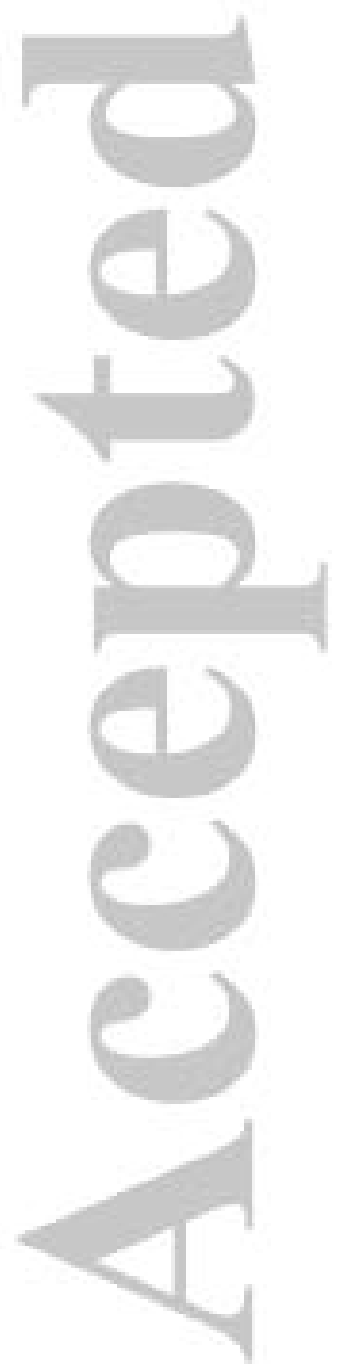



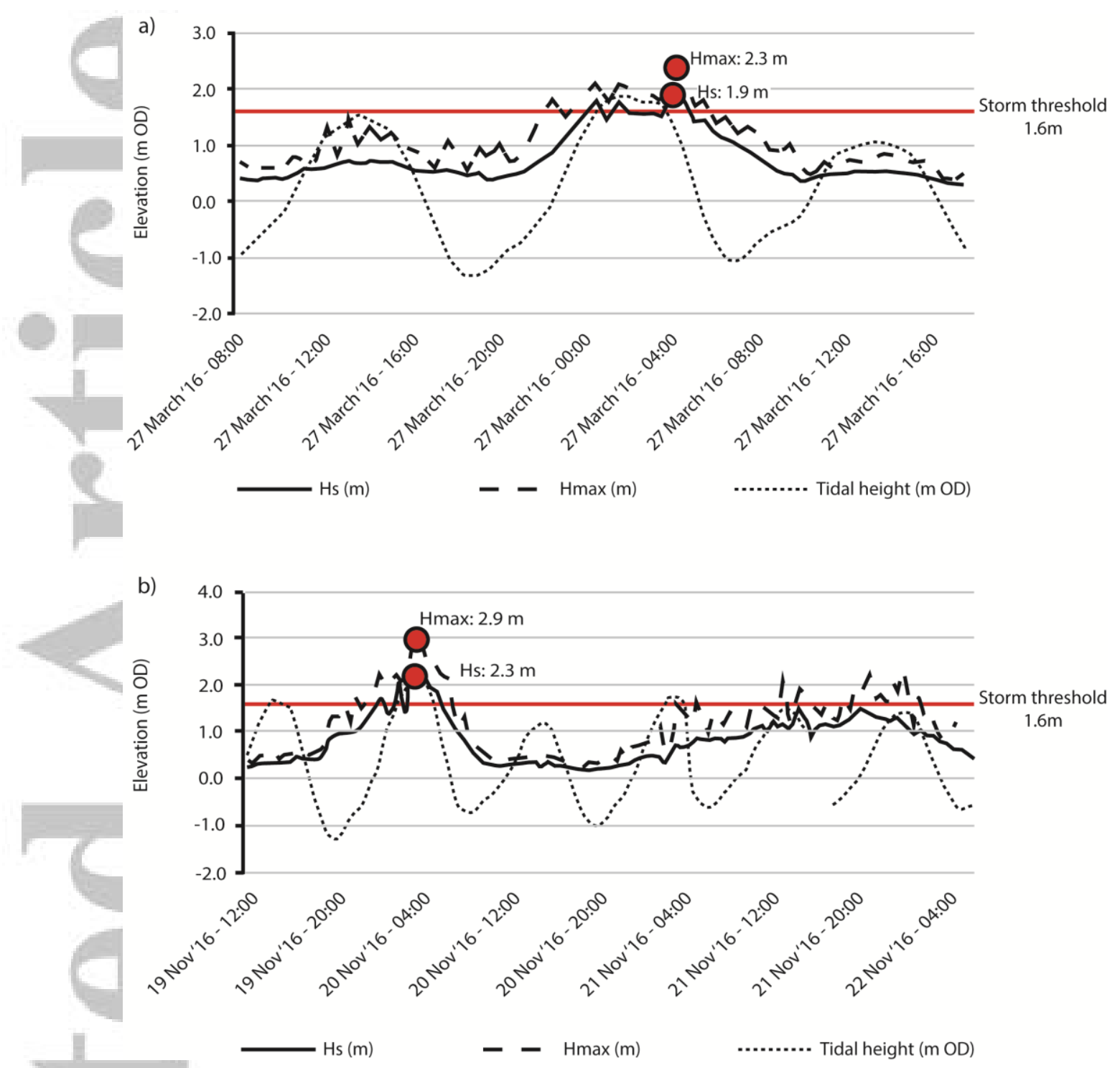

Figure. 18. Peak wave activity $\left(\mathrm{H}_{\mathrm{s}}\right.$ and $\left.\mathrm{H}_{\max }\right)$ and tidal height relative to the $\mathrm{CCO}$ storm threshold of $1.6 \mathrm{~m}$. The circles represent peak wave values as indicated. Wave and tidal conditions associated with (a) Storm Katie and (b) Storm Angus. 

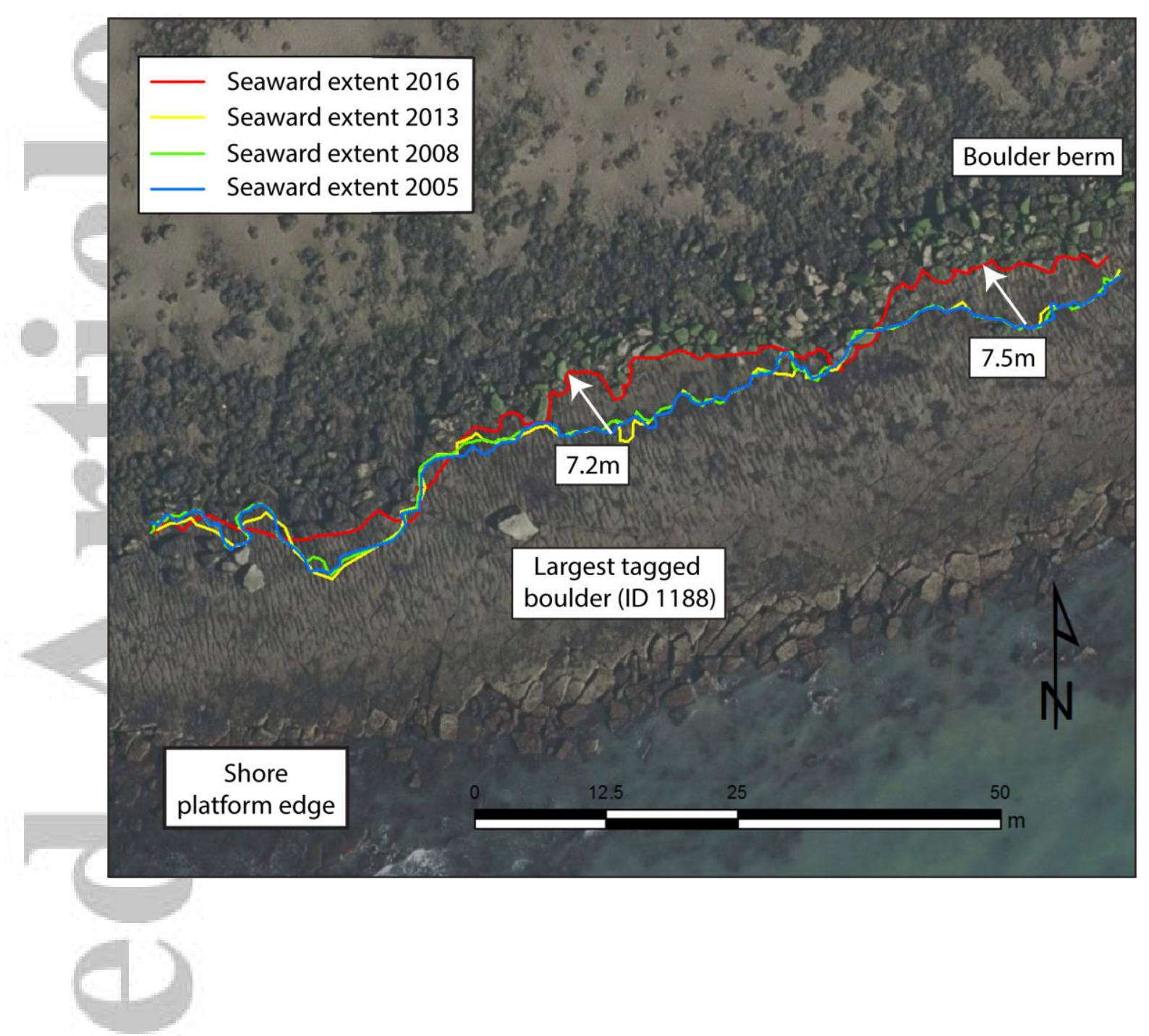

Figure 19. Large-scale geomorphic modification to the boulder berm at Black Rock.

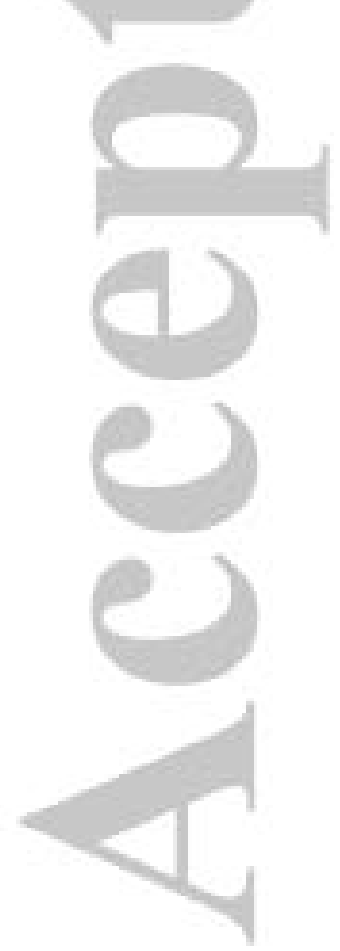

This article is protected by copyright. All rights reserved. 